UNITED STATES DEPARTMENT OF THE INTERIOR

Harold L. Ickes, Secretary

GEOLOGICAL SURVEY

W. C. Mendenhall, Director

\title{
Bulletin 931-G
}

\section{CHROMITE DEPOSITS OF KENAI PENINSULA, ALASKA}

\author{
BY \\ PHILIP W. GUILD
}

Strategic Minerals Investigations, 1941

(Pages 139-175)

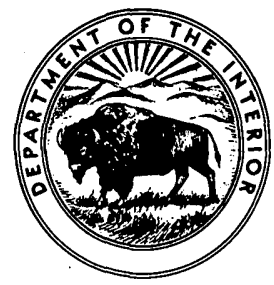

UNITED STATES

GOVERNMENT PRINTING OFFICE

WASHINGTON : 1942 



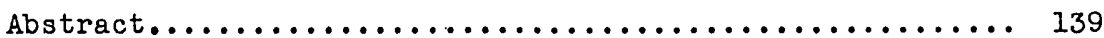

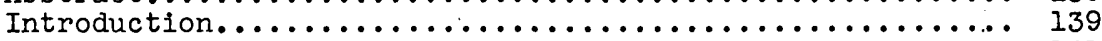

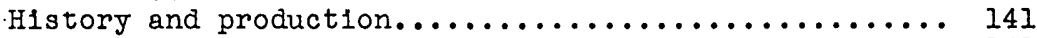

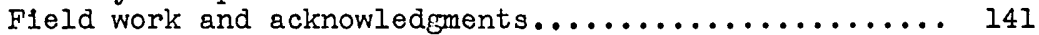

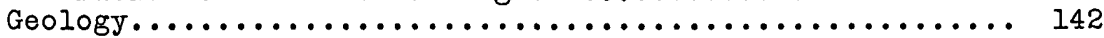

Metamorphic, sedimentary, and extrusive rocks....... 143

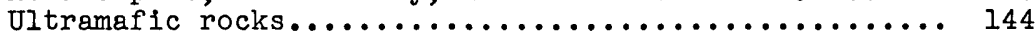

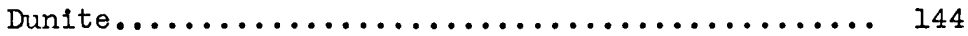

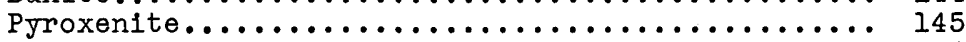

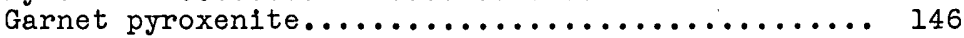

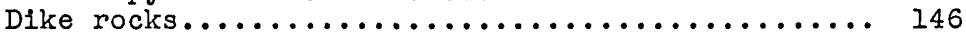

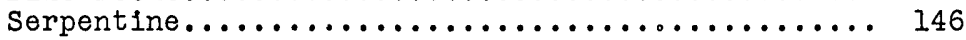

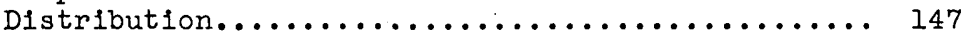

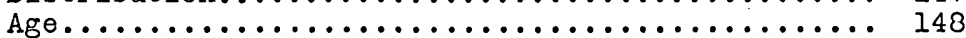

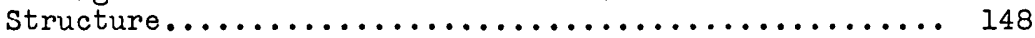

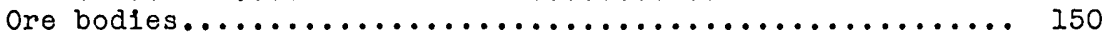

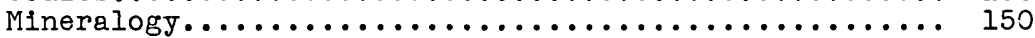

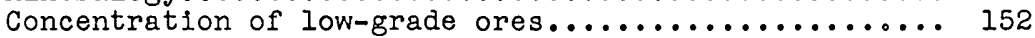

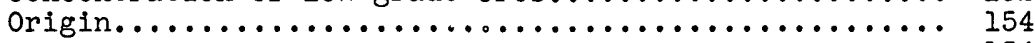

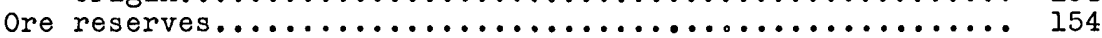

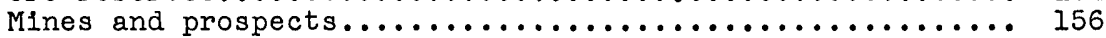

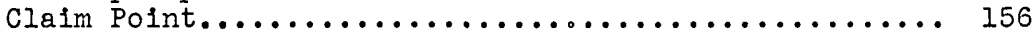

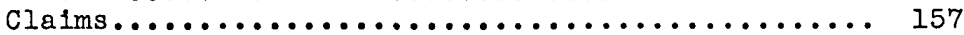

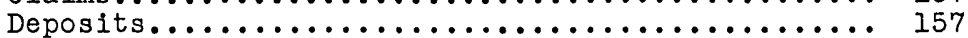

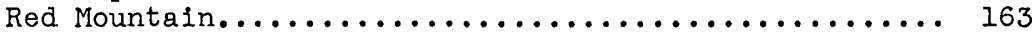

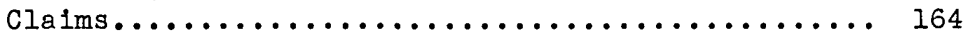

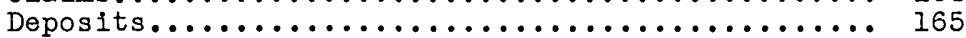

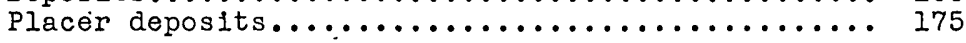

\section{ILLUSTRATIONS}

Plate 24. Geologic reconnaissance map of the southwestern

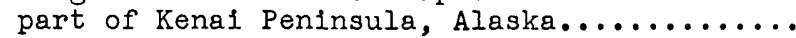

25. Geologic map of Claim Point, Kenai Peninsula,

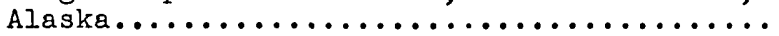

26. Geologic and topographic map of Red Mountain, Kenai Peninsula, Alaska............. In pocket 27. Map showing mining claims at Red Mountain, Alaska............................ 166

28. Plan and geologic map of the Star No. 4 ore body, Red Mountain, Alaska.............. 166

29. A, View of Red Mountain, from the northwest.... 166 $\underline{\bar{B}}$, Banded ore 20 feet north of shaft, Star

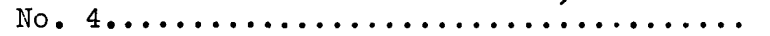


Plate 30. A, Banded disseminated ore, deposit No. 20, Red

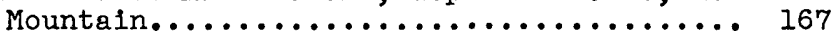
B, Chromite lens cut by fresh olivine dikelets, deposit No. Il, Claim Point............. 167 31. A, Drag fold in chromite, deposit No. 24, Red

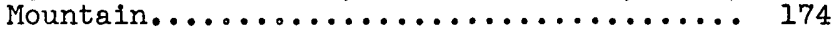
Figure 11. Index map of Alaska, showing area included in 174

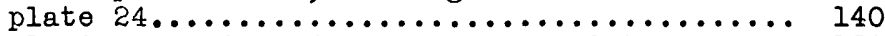
12. Geolog1c map of Reef mine, Claim Point........ 159 13. Geologic map of the Bluff No. 1 deposit, Claim

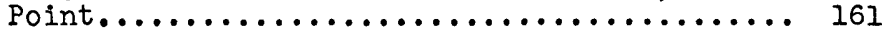
14. Block diagram of deposit No. 5, Red Mountain... 168 15. Sketch map of Juneau No. 1 deposit, Red Moun-

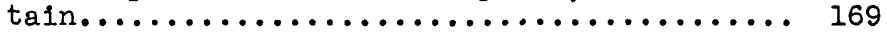




\title{
CHROMITE DEPOSITS OF KENAI PENINSULA, ALASKA
}

\author{
By Philip w. Guild
}

\section{ABSTRACT}

Chromite deposits occur at the south end of Kenai Peninsula, Alaska, in two areas, Claim Point and Red Mountain. They are contained in masses of ultramafic rocks (those with unusually large contents of magnesium and iron), which are intrusive into a complex series of graywackes, slates, and cherts of Paleozoic (?) age. Dunite is the predominant intrusive; pyroxenite, garnet pyroxenite, and serpentine derived from the alteration of dunite are also present.

Chromite grains are distributed in small quantity throughout the dunite; the ore deposits are parts of the dunite and serpentine masses in which chromite has been concentrated by magmatic segregation. These deposits are tabular, strongly banded bodies, which range in size from stringers to bodies containing more than 50,000 tons, and in grade from a few percent to 50 percent of chromic oxide $\left(\mathrm{Cr}_{2} \mathrm{O}_{3}\right)$. Analyses of the chromite alone, separated from the silicate gangue, show that it usually contains 54 to 59 percent of $\mathrm{Cr}_{2} \mathrm{O}_{3}$ and has a chrome-iron ratio of $3: 1$ or greater. The reserves are estimated to contain 150,000 tons of chromite. About 73,000 tons of the chromite is in shipping ore, contalning 40 percent or more of $\mathrm{Cr}_{2} \mathrm{O}_{3}$; the remaining 77,000 tons is in some 170,000 tons of lower-grade ore, which will require concentration to produce a marketable product.

Transportation difficulties have retarded the development of the Red Mountain area, which is 6 miles from tidewater, and they will add to the cost of mining. Claim Point is easily accessible by boat.

\section{INTRODUCTION}

Two areas of ultramaflc rocks containing chromite deposits are known at the south end of Kenai Peninsula, Alaska, (see fig. 11), near the town of Seldovia. (See pl. 24.) The smaller and more readily accessible area is at Claim Point, which projects into Port Chatham, 17 miles south-southwest of Seldovia by air line, and 30 miles from it by boat. The village of Portlock, near the head of Port Chatham, is 3 miles away. The Claim Point 
intrusive has an area above sea level of somewhat more than a quarter of a square mile. The relief is comparatively low, as the highest point has an altitude of only 268 feet, and exposures are poor except along the shore.

The other area is at Red Mountain, 10 miles south-southeast of Seldovia. A $5 \frac{1}{2}-m i l e$ trail connects it with the head of Jakolof Bay, which is 11 miles northeast from Seldovia along the coast. The Red Mountain area of ultramafic rocks is roughly elliptical and 4 miles long by 2 miles wide, with an area of ap-

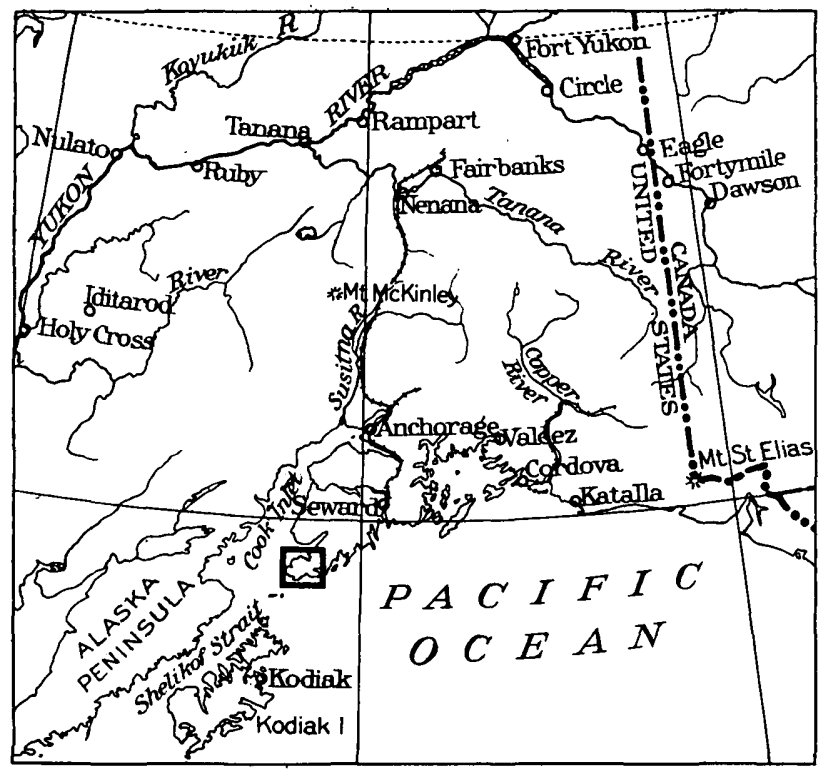

Figure 11.--Index map of Alaska, showing area included in plate 24.

proximately 7 square miles. The relief is from 970 to 3,470 feet above sea level.

Seldovia, a town of about 400 people, is 2,000 miles by ship from seattle. It is a port of call for the southwest Alaska line of the Alaska Steamship Co., which maintains a weekly schedule in summer and a fort-nightly schedule in winter. Several motorships plying between seward and Anchorage make frequent calls, and a radio station keeps seldovia in communication with the rest of the world. 


\section{History and production}

Although the existence of chromite deposits at Claim Point and Red Mountain has been known for at least 30 years, production has been restricted to two years' output from a single ore body at Claim Point. Under the stimulus of war-time prices, approximately 1,000 tons of ore, averaging 46 to 49 percent of $\mathrm{Cr}_{2} \mathrm{O}_{3}$ was mined in 1917, and 1,000 tons, averaging 40 percent, in 1918. $2 /$ The decline in tenor is reported to have been due to a lowering of specifications by the purchaser. With the collapse of the market at the close of the war, all mining activity ceased. To date (March 1941) there has been no further production, although prospecting and some development work have been carried on.

Grant $3 /$ visited these deposits in 1909, while reconnoltering the mineral resources of Kenal Peninsula. Mertie $4 /$ examined them briefly in 1917. In $1918 \mathrm{~A}$. C. Gill spent 7 weeks studying the ore bodies and their geological environment. His final report, Bulletin 742, includes maps of the two areas and descriptions of most of the ore bodies known at the present time.

\section{Field work and acknowledgments}

The field work for the present investigation was carried out from June 20 to september 23, 1940. Approximately three weeks were spent at Claim Point and eleven weeks at Red Mountain. The writer was assisted by R. J. Anderson, R. E. I. Rutledge, and

1/ Grant, U. S., and Higgins, D. F., Preliminary report on the mineral resources of the southern part of Kenal Peninsula: U. S. Geol. Surver Bull. 442, pp. 168-169, 1910.

2) Gill, A. C. Chronite of Kenal Peninsula, Alaska: U. S. Geol. Survey Bull. 742, pp. 1, 20, 1922.

3/ Grant, U. S., and Higgins, D. F., op. c1t. Mart1n, G. C., Jahnson, B. I., and Grant, $\ddot{U}$. S., Geology and mineral resources of Kenal Peninsula, Alaska: U. S. Geol. Survey Bull. 587, pp. 237-238, 1915.

4/ Mertie, J. B., Jr., Chromite deposits in Alaska: ठ. S. Geol. Survey Bul1. 692, pp. $265-267$, igig.

5/ Gill. A. C.. Prellminary report on the chromite of Kenal Penlnsula: U. S. Geol. Survey Bull. 712, pp. 99-129, 1920; Chromite of Kenal Peninsula, Aleska: U. S. Geol. Survey Bull. $742,1922$. 
W. L. Welnmann, Jr. The Claim Point area was mapped both topographically and geologically on a scale of 400 feet to the inch, Red Mountain on 1,000 feet to the inch, and several individual deposits on larger scales. Channel samples were taken across all the important ore bodies.

The writer is indebted to many residents of the region for their valuable assistance in carrying out the work, and in particular to Francis Lass and G. P. Kearnes, whose hospitality and knowledge of the country were greatly appreciated. P. S. Smith, H. G. Ferguson, and F. C. Calkins, of the Geological Survey, contributed many helpful suggestions and criticisms during the preparation of this report. Analyses of ore samples were made by. R. E. Stevens in the chemical laboratory of the Geological Survey.

\section{GEOLOGY}

The general geologic setting of the chromite deposits is shown on plate 24, based on the work of Martin, Johnson, and Grant, $6 /$ with revisions by A. C. Gill. ?/ The oldest rocks in southern Kena1 Peninsula, with the possible exception of a narrow belt of crystalline schists near Seldovia, are a thick series of graywackes, slates, cherts, limestones, and interbedded volcanic rocks. This series underlies nearly all the mountainous southern part of the peninsula. It is overlain on the west by ellipsoidal lavas and fossiliferous Upper Triassic limestones, which are in turn unconformably overlain by Lower Jurassic tuffs. The graywacke series has been assigned a probable Paleozolc age by Martin. $8 /$

The ultramafic rocks at Claim Point and Red Mountain are discordant intrusives into the graywacke serles. The predomi-

6/ Kartin, G. C.. and others, op. cit., pl. 3.

7) Gill, A. C.. op. c1t. (Bull. 742), pl. 1 .

8) Martin, G. C., and others, op. c1t.. pp. 44-49. 


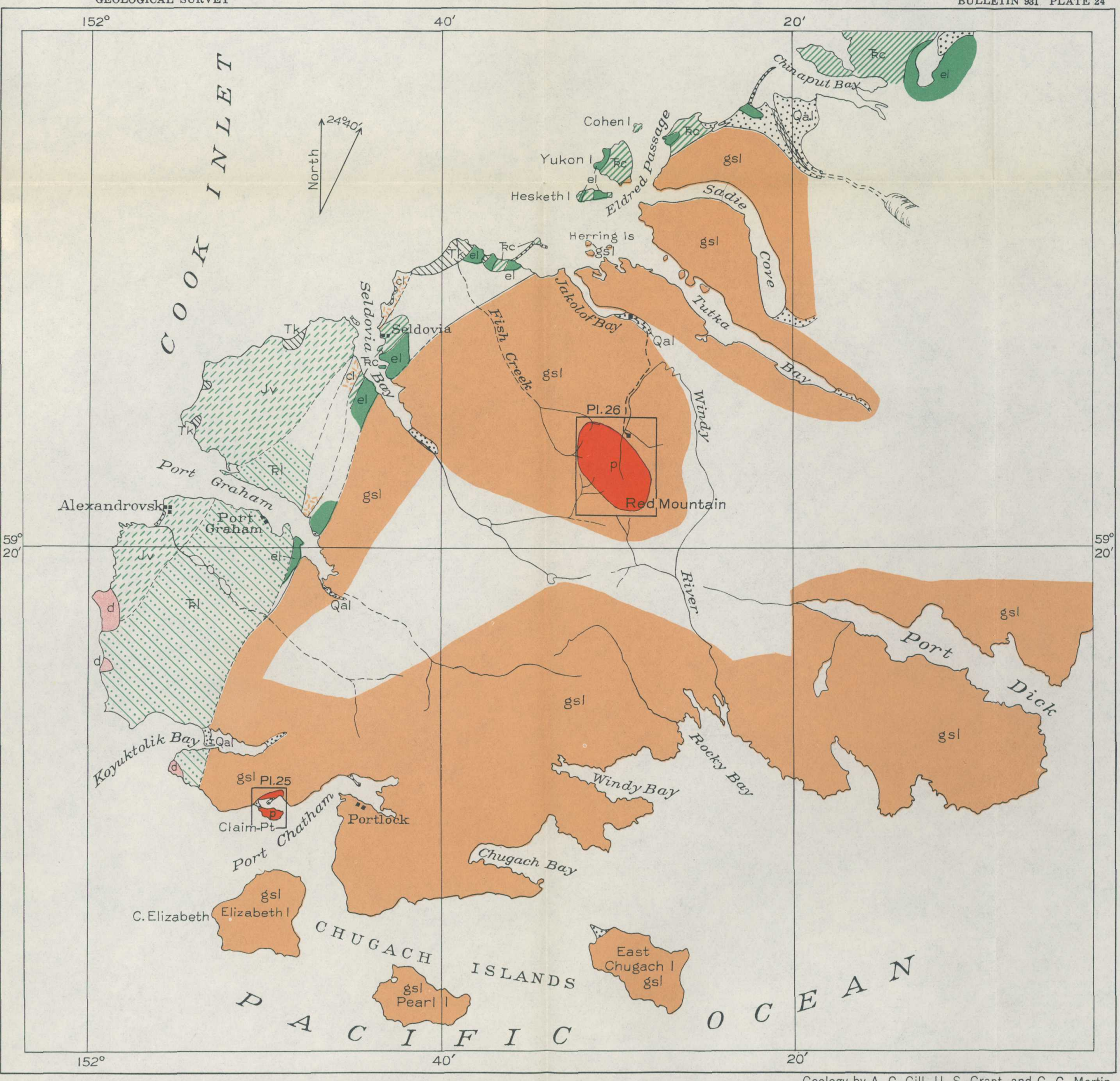

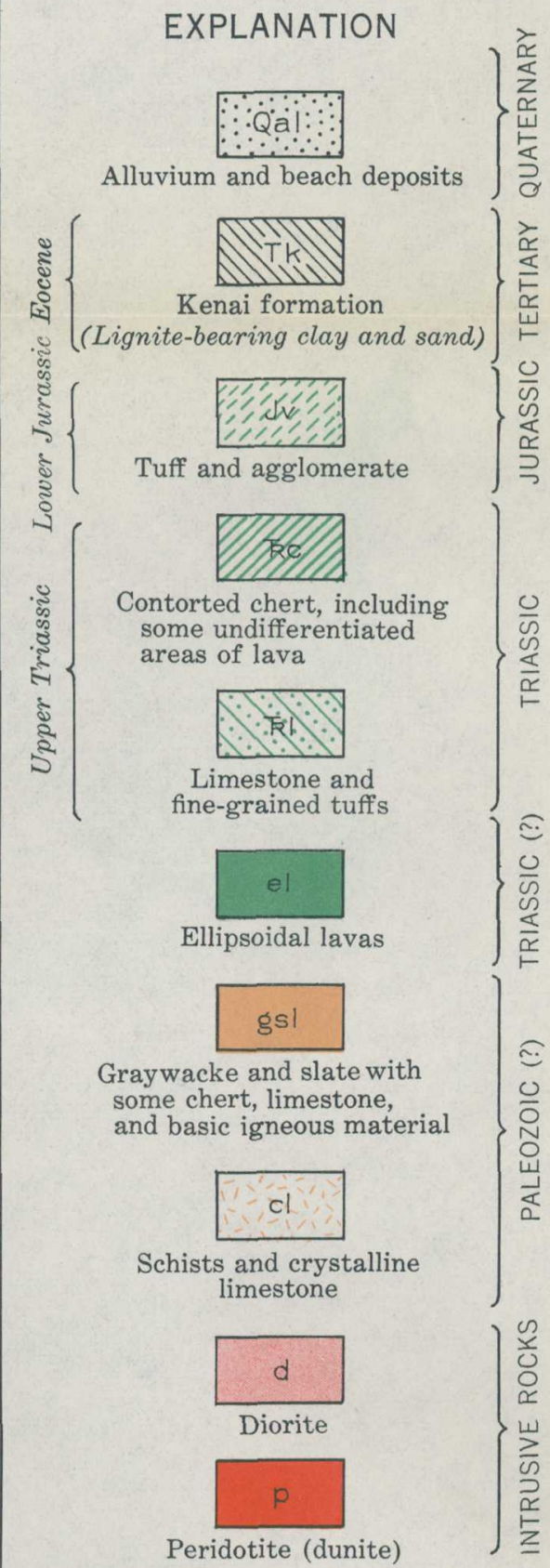

GEOLOGIC RECONNAISSANCE MAP OF THE SOUTHWESTERN PART OF KENAI PENINSULA, ALASKA 
nant rock is dunite, which forms nearly all the Claim Point mass and perhaps 90 percent of the Red Mountain mass, in which pyroxenite and garnet pyroxenite constitute the other 10 percent. Along the margin of each mass the dunite has been altered to serpentine. The chromite deposits occur in the dunite.

The only other intrusives in the region are dioritic rocks which cut all the sedimentary and metamorphic rocks up to and including the Lower Jurassic tuffs.

The Kenai Peninsula was strongly glaciated in Pleistocene and Recent time, and to the northeast it is still covered by a thick ice cap which extends to within 20 miles of Red Mountain. Evidences of glacial action at Claim Point are the polishing and grooving of the dunite along the south shore, the "roches moutonnées" In the swamp, and the thin veneer of till exposed in many places. At Red Mountain the numerolis cirques and moraines and the typical U-shaped valley of Windy River give unmistakable proof of glaciation.

Since the disappearance of the ice, currents and waves have built up the gravel bar which connects Claim Point with the mainland, and also the recurved spits nearly enclosing the lagoon north of the point. At Red Mountain huge talus slopes have formed at the base of the cliffs. Streams have cut down into the underlying rock, especially along the less resistant serpentinized contact zone. These streams have built low alluvial fans on the valley floor.

\section{Metamorphic, sedimentary, and extrusive rocks}

The metamorphic, sedimentary, and extrusive rocks were not investigated for the present report; a full description of them is given in the general report on the Kenai Peninsula. $9 /$ The Paleozolc (?) rocks, which surround the ultramaflc bodles, are

9/ Martin, G. C., and others, op. c1t., pp. 41-97, 209-228. 
for the most part a drab-gray or greenish-gray mass in which bedding is often indistinguishable. The cherts, however, which range from white to dark gray, usually show bedding and reveal that the Paleozolc (?) rocks were severely deformed before the intrusion of the igneous rocks.

\section{Ultramafic rocks}

The ultramafic rocks are characterized chemically by their high content of magnesium and iron, low silica and alumina, and almost complete absence of alkalies. This composition is expressed mineralogically by the predominance of olivine and pyroxene, the absence of quartz, and the highly calcic composition of what little feldspar is present. Chromite, the world over, is associated with rocks of this type.

\section{Dunite}

The dunite consists almost entirely of olivine, ( $\mathrm{Mg}, \mathrm{Fe})_{2} \mathrm{SiO}_{4}$, with accessory chromite grains, averaging about 0.5 millimeter across, which usually constitute less than 1 percent of the rock. On fresh surfaces the rock shows a dense texture and a greenishgray color, but weathered outcrops have a smooth reddish or yellowish ilmonitic surface. As soil formed from the dunite is infertile it is washed away almost as rapidly as it is formed. For this reason Red Mountain stands out sharply from the grassand alder-covered slopes of the surrounding metamorphosed rocks. At Claim Point the mantle of till supports a luxurlant growth, and the dunite is not so conspicuous.

Thin sections reveal two sizes of olivine crystals, ragged, elongated grains 1 to 4 millimeters long, surrounded by much smaller grains. The large grains have been severely strained and they show strong undulatory extinction, which is much less marked in the interstitial olivine. The large grains apparently were strained and fractured before the small grains crystallized. 
The dunite is usually not entirely fresh. In most of it the grains of olivine are surrounded by shells of serpentine, but serpentinization is observable in all stages, from that in which narrow veinlets of serpentine cut fresh olivine to that in which the dunite has been altered to follated soft green serpentine in which no trace of olivine remains. This change from fresh dunite to serpentine is marked by a progressive deepening of the color of the fresh surface from gray green through deeper shades of green to a dense black which is not easily distinguishable from the chromite at a little distance. The weathered surface of the serpentinized dunite is an olive drab, darker for the more serpentinized rock.

\section{Pyroxenite}

The only other common ultramafic rock is a green pyroxenite consisting almost entirely of diallagic augite. The pyroxene cleavages and rough, greenish-gray, weathered surfaces distinguish this rock from dunite. Chromite is seldom seen, except in thin sections, and no ore bodies are known to occur in the pyroxenite.

The pyroxenite forms layers in the dunite ranging in thickness from less than an inch to about 200 feet. Thin parallel layers of pyroxene-rich rock weather in relief, giving outcrops a cormagated appearance.

The pyroxenite was very resistant to serpentinization. Lenses of pyroxenite completely surrounded by serpentinized dunIte appear unaltered on fresh surfaces, although the joints are covered with a thin film of serpentine. Under the microscope some antigorite is seen, which has been derived, presumably, from interstitial olivine. Pseudomorphs of bastite after an orthorhombic pyroxene, and a little chlorite are also present occasionaliy. 


\section{Garnet pyroxenite}

Garnet pyroxenite is found in one small area on Red Mountain. It is a massive rock consisting almost entirely of pink garnet and green diallagic augite in nearly equal amounts. A little chlorite has developed from the pyroxene. Chromite is present in small grains, some interstitial to the silicate minerals. This rock has been extremely resistant to both serpentinization and weathering. No ore bodies are associated with it.

\section{Dike rocks}

Narrow dikes, usually less than an inch thick, but in one place 3 feet across, cut the primary banding. They include ollvine (see plate $30, \underline{B}$ ), pyroxene, and hornblende dikes, as well as dikes made up of mixtures of these minerals. At Red Mountain, dikelets containing a large proportion of anorthite, together with hornblende, olivine, pyroxene, garnet, and a green spinel mineral, are prominent because the anorthite is the only lightcolored silicate found within the intrusive body.

\section{Serpentine}

Serpentine is the product of alteration of the magnesian silicates which make up the ultramafic rocks. The alteration took place soon after the intrusion of these rocks, and was the result of hydration of the silicates by hot waters probably derived from the magma itself. The olivine altered much more readily than the pyroxene, and most of the serpentine was formed from dunite. The completely serpentinized dunite is a soft, foliated, dark-green rock which breaks easily along innumerable polished and slickensided surfaces. The alteration from olivine to serpentine involved a considerable increase in volume, which In turn produced shearing. Many ore bodies in the serpentine zone have been broken up by this shearing, as the slickensided 
fragments show. No large bodies of chromite are known to exist in the serpentine.

\author{
Distribution
}

Dunite forms nearly all the Claim Point intrusive (pl. 25). No pyroxenite is present, although certain layers exposed along the south and west shores of the point contain a little augite. A few narrow olivine-pyroxene dikelets cut the Reef ore body, and are also present at scattered points along the south shore and elsewhere. The dunite on the point itself is fairly fresh, but exposures along the shore of the mainland show much serpentinization. The contact with the enclosing country rock is revealed at only two points, where 1t crosses the shore northwest and northeast of Claim Point Hill. At these points the intrusive rock is completely altered to green, sheared serpentine.

Dunite and the serpentine derived from it comprise perhaps 90 percent of the Red Mountain intrusive, (see pl. 26), and pyroxenite most of the remainder. The pyroxenite layers are parallel to one another and to the chromite-rich layers in the dun1te. They are best exposed in the high ridge west of Windy River, but their apparent abundance there as compared with other parts of the area is due in part to a favorable combination of attitude and relief. A small area a quarter of a mile north of the pyramidal peak which stands between the passes into seldovia River from Windy River was mapped as undifferentiated dunite and pyroxenite because the many thin alternating bands could not be distinguished on the map scale used. The average composition of this rock would be a peridotite with perhaps 50 percent each of olivine and pyroxene, but each individual band shows almost pure olivine or pyroxene. The garnet pyroxenite, ore bodies, and dikes probably do not aggregate 1 percent of the total mass. Garnet pyroxenite occurs in three small outcrops north of the small lake near the northern limit of the area. A zone of 
serpentine from 100 feet to half a mile wide extends around the margin of the mass.

$$
\text { Age }
$$

The ultramafic rocks intrude the Paleozoic (?) graywacke series discordantly. Siliceous dikes cut the Lower Jurassic tuffs and all the older sedimentary and metamorphic rocks of the region, but not the ultramafic intrusives. As the siliceous and ultramafic rocks were not seen in contact with one another, their relative ages could not be determined definitely, but it seems probable that the ultramafics are younger. No Igneous rocks are known in the Tertiary deposits of western Kenal Peninsula. $10 /$ The chromite-bearing intrusives are tentatively assigned a late Jurassic or Cretaceous age.

\section{Structure}

The regional structures have a general northeasterly trend, but their detalls have not been worked out. The sedimentary and metamorphic rocks were complexly folded before the intrusion of the ultramafic rocks, which cut across the bedding discordantly.

The contact of the Red Mountain mass, where actually observed, ranges from vertical to a dip of $45^{\circ}$ toward the center. of the mass. The course of the contact across the hills and valleys indicates that it must in general be very steep. The poor exposures and low relief at Claim Point make the attitude of the contact there uncertain, but it also is probably steep. No ultramafic dikes are known to have been intruded into the surrounding sedimentary and metamorphic rocks.

The outstanding feature of the intrusive bodies is the banding, which is of common occurrence in rocks of this general type. The bands are the outcrops of chromite- or pyroxene-rich lajers in the dunite, (see pls. 29, B, 30, A), which in any one area 
are.more or less parallel and which never intersect. The layerIng is an original structure in the rock, antedating the consolidation of the magma. As a rule the strike and dip of the layers are constant throughout the length of an exposure, but in a few places thin layers of pyroxenite and chromite are sharply curved.

The only prominent bands at Claim Point are of chromite. They range from a fraction of an inch to several feet in width, and from a few feet to a hundred feet or more in length. The layers that they represent strike about N. $75^{\circ} \mathrm{E}$. and dip vertically or steeply south, but the attitude of a few differs widely from this. Not enough of the intrusive is exposed to determine the relation of the layering to the contact.

Banding is so conspicuous in the Red Mountain intrusive as to give it a stratified appearance. The layers strike parallel to the contact around three sides of the mass, and change in dip from almost vertical near the contact to horizontal near the pyramidal peak between the two low passes from Windy River into Seldovia River. The structure is essentially an elongate basin whose major axis trends north-northwest. To the south and southeast of the pyramidal peak the layers dip rather gently in what seem to be random directions. Sharp folds in thin chromite and pyroxenite layers, with their axes parallel to the axis of the basin, are considered to be drag folds formed in the weaker layers during a down-warping of the layered mass while it was still somewhat plastic, perhaps in the "crystal mush" state. (See pl. 3l, A, B..)

Faulting and jointing are very common at both Claim Point and Red Mountain. The faults may be divided roughly into two types on the basis of their apparent age. Early faults show drag of the thin bands, and many are completely healed. Like the drag folds, to which they are genetically related, they antedate the final consolidation of the magma. On some early 
fault planes movement has been renewed, often in the opposite direction, as shown by "reverse drag". Later faults show no drag, are not healed, and many show slickensides of serpentine or crushed chromite. Displacements of a foot or two are common, and some of a few tens of feet occur, but no large faults have been found and it is unlikely that the faults would seriously hamper mining operations. In the serpentinized zones, however, it is impossible to say how much faulting has occurred or what 1ts magnitude was.

\section{ORE BODIES}

The ore bodies are layers or lenses in which chromite is much more highly concentrated than it is in the normal dunite. They range in size from mere streaks to bodies several hundred feet long and from 1 to 50 feet thick. Their distribution is apparently irregular, and although each ore body is more or less parallel to nearby pyroxentte bands and other ore bodies, no predictions can be made as to the possible occurrence of unexposed deposits. The proportion of chromite in the enriched layers ranges from more than 90 percent down to a percentage little greater than that in the normal dunite.

\section{Mineralogy}

Chromite is a black opaque mineral with a submetallic luster, belonging to the spinel group of the isometric class. It is distinguished from magnetite by its brown streak and low degree of magnetism. Its theoretical chemical composition is $\mathrm{FeO}_{2} \mathrm{Cr}_{2} \mathrm{O}_{3}$, with 32 percent $\mathrm{FeO}$ and 68 percent $\mathrm{Cr}_{2} \mathrm{O}_{3}$, but in fact it always contains $\mathrm{MgO}, \mathrm{Fe}_{2} \mathrm{O}_{3}$, and $\mathrm{Al}_{2} \mathrm{O}_{3}$. Its formula, therefore, is usually written as $(\mathrm{Fe}, \mathrm{Mg}) \mathrm{O}_{0}(\mathrm{Cr}, \mathrm{Al}, \mathrm{Fe})_{2} \mathrm{O}_{3^{\circ}}$. The percentage of $\mathrm{Cr}_{2} \mathrm{O}_{3}$ in the mineral may thus range between wide limits, but with few exceptions its range in the deposits under discussion is small and the percentage of $\mathrm{Cr}_{2} \mathrm{O}_{3}$ near 58 . 

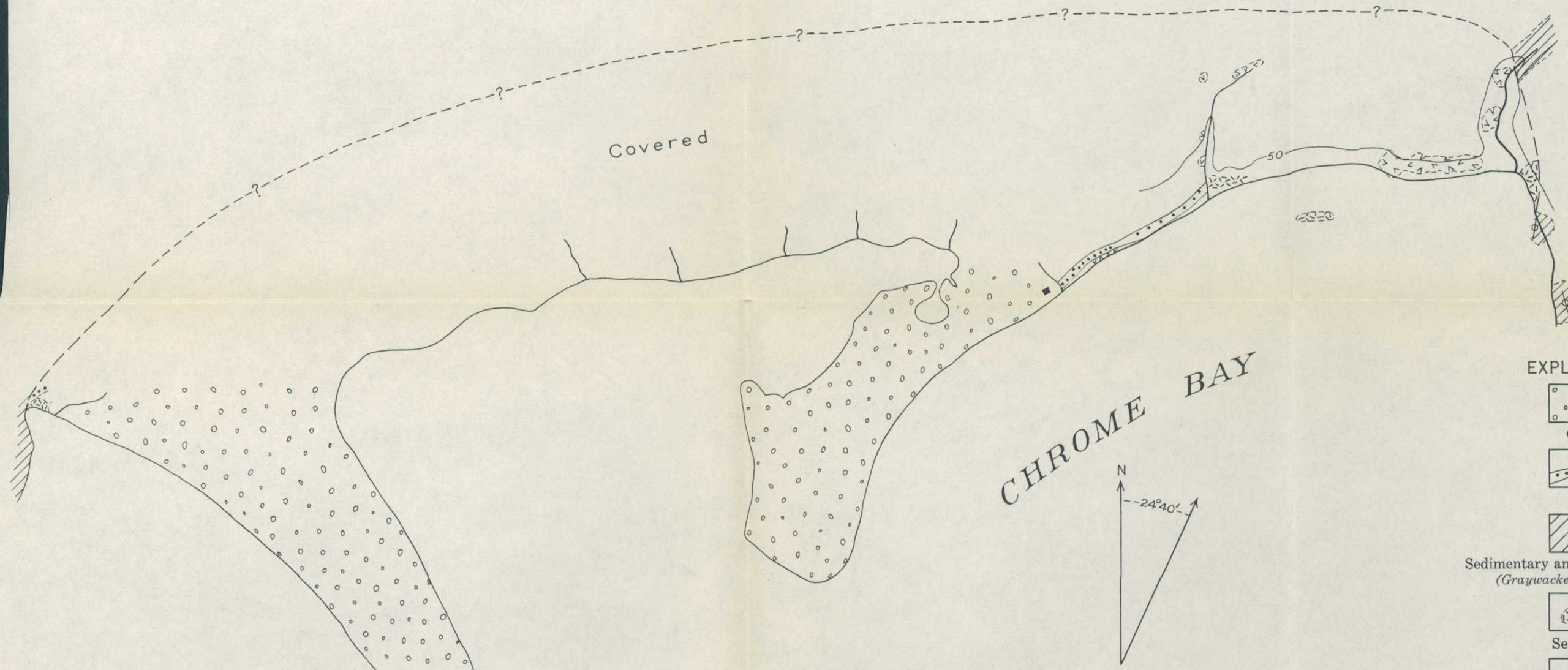

$B^{A Y}$
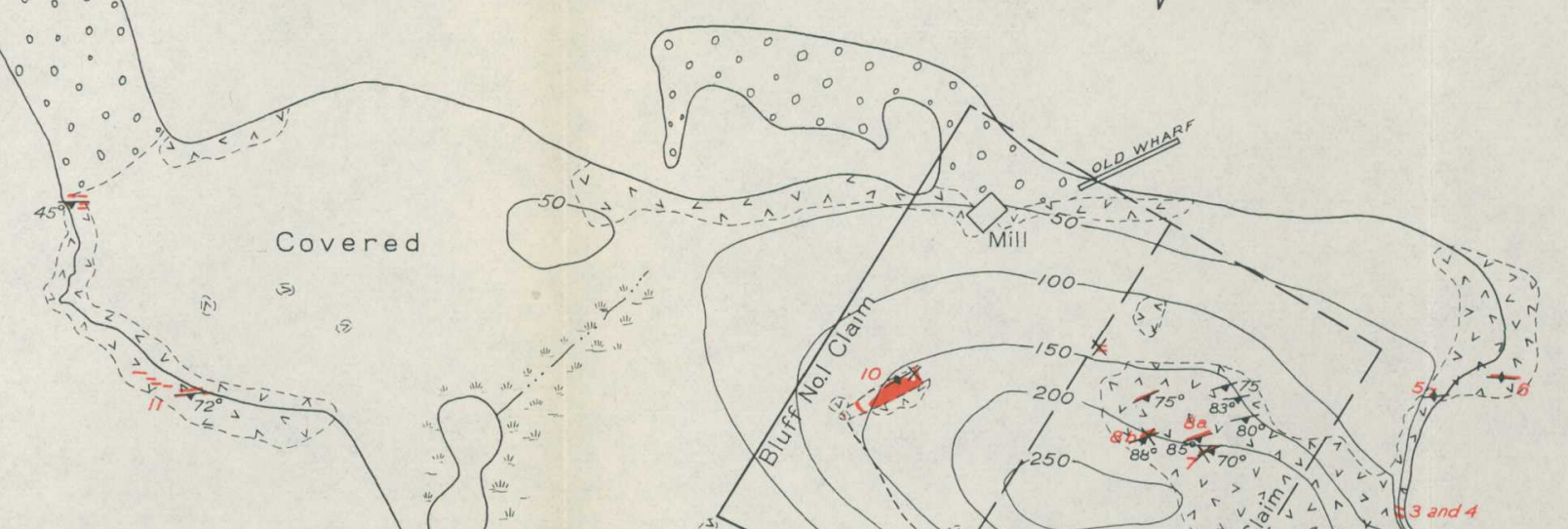

\section{Strike of vertical layering \\ Vertical bedding} Strike and dip of layering
in igneous rocks in sedimentary rocks

Contact of igneous rocks
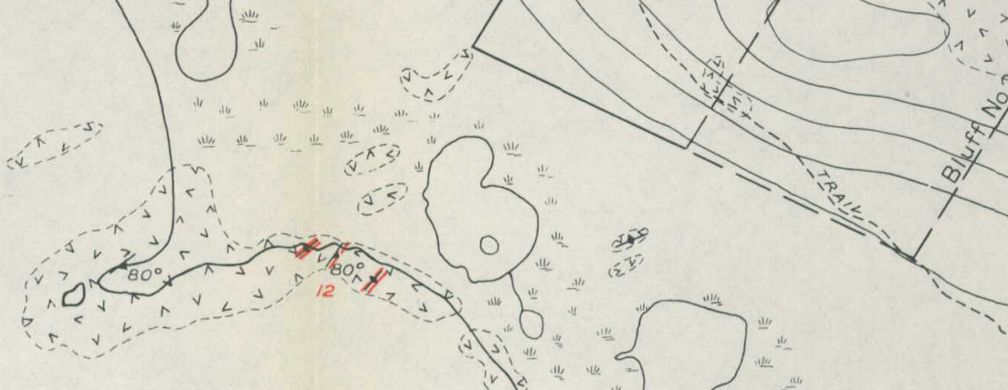

(and $-?--?$ course of contact

Mine

$\stackrel{x}{x}$

GEOLOGIC MAP OF CLAIM POINT, KENAI PENINSULA, ALASKA 
The following partial analyses, made in the chemical laboratory of the Geological Survey, show the chromium and iron content of some typical ores from Kenal Peninsula. The third and fourth columns of the table apply to the ore as sampled, with no concentration; the last three columns apply to the pure mineral chromlte, separated from the silicate gangue with heavy liquids.

Partial analyses of chromite from Kenai Peninsula, Alaska [R. E. Stevens, analyst]

\begin{tabular}{|c|c|c|c|c|c|c|c|}
\hline \multirow{2}{*}{\multicolumn{2}{|c|}{$\begin{array}{c}\text { Ore body } \\
\text { No. }\end{array}$}} & \multirow[b]{2}{*}{$\begin{array}{l}\text { Sam- } \\
\text { ple } \\
\text { No. }\end{array}$} & \multicolumn{2}{|c|}{ Ore } & \multicolumn{3}{|c|}{ Concentrate } \\
\hline & & & $\begin{array}{c}\mathrm{Cr}_{2} \mathrm{O}_{3} \\
\text { (percent) }\end{array}$ & $\begin{array}{l}\text { Chromite } \\
\text { (percent) }\end{array}$ & ${ }_{(\text {percent) }}^{\mathrm{Cr}_{2} \mathrm{O}_{3}}$ & $\begin{array}{c}\mathrm{FeO} I \\
\text { (percent) }\end{array}$ & $\mathrm{Cr}: \mathrm{Fe}$ \\
\hline $\begin{array}{l}1 \\
1 \\
1\end{array}$ & $\begin{array}{l}\text { Claim } \\
\text { Point }\end{array}$ & \begin{tabular}{r|}
1 \\
9 \\
14
\end{tabular} & $\begin{array}{l}35.8 \\
47.6 \\
32.3\end{array}$ & $\begin{array}{l}66 \\
83 \\
55\end{array}$ & $\begin{array}{l}54.2 \\
57.6 \\
59.0\end{array}$ & $\begin{array}{l}16.5 \\
14.6 \\
15.6\end{array}$ & $\begin{array}{l}2.9: 1 \\
3.5: 1 \\
3.3: 1\end{array}$ \\
\hline $\left.\begin{array}{l}8 \\
11 \\
2\end{array}\right\}$ & $\begin{array}{l}\text { Red } \\
\text { Moun- } \\
\text { tain }\end{array}$ & $\begin{array}{l}19 \\
27 \\
33\end{array}$ & $\begin{array}{l}44.3 \\
24.4 \\
52.1\end{array}$ & $\begin{array}{l}75 \\
42 \\
90\end{array}$ & $\begin{array}{l}59.2 \\
58.4 \\
58.2\end{array}$ & $\begin{array}{l}14.4 \\
19.7 \\
14.8\end{array}$ & $\begin{array}{l}3.6: 1 \\
2.6: 1 \\
3.5: 1\end{array}$ \\
\hline
\end{tabular}

1) Total Iron as $\mathrm{FeO}$.

At least nine-tenths of the ore contains chromite that falls within the range indicated by these analyses. A few deposits, however, contain chromite that differs widely in composition from the normal chromite of the region, as shown by analyses 43 , 45 , and 46 in the following table.

Analyses of chromite from Kenai Peninsula, Alaska [R. E. Stevens, analyst]

\begin{tabular}{|c|c|c|c|c|}
\hline 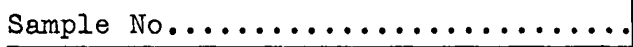 & 43 & 44 & 45 & 46 \\
\hline 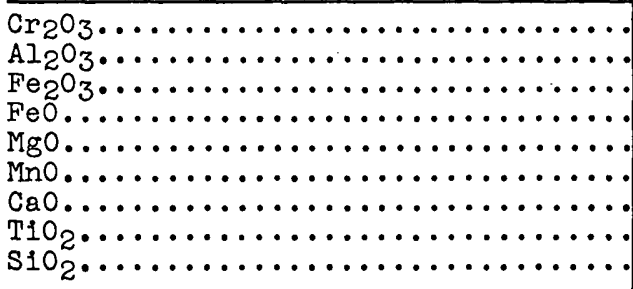 & $\begin{array}{r}34.81 \\
22.93 \\
10.57 \\
21.47 \\
9.74 \\
.22 \\
.06 \\
.56 \\
.08 \\
\end{array}$ & $\begin{array}{r}57.83 \\
9.90 \\
3.89 \\
15.12 \\
12.55 \\
.20 \\
.06 \\
.16 \\
.36 \\
\end{array}$ & $\begin{array}{r}48.55 \\
15.83 \\
7.22 \\
16.19 \\
11.78 \\
.18 \\
.10 \\
.44 \\
.10 \\
\end{array}$ & $\begin{array}{r}48.45 \\
14.43 \\
6.93 \\
17.71 \\
11.03 \\
.24 \\
.16 \\
.48 \\
.34 \\
\end{array}$ \\
\hline & $1 \overline{00.44}$ & 100.07 & 100.39 & $\overline{99.77}$ \\
\hline $\begin{array}{l}\text { Cr:Fe } \ldots \ldots \ldots \ldots \ldots \\
\text { Percent of } \mathrm{cr}_{2} \mathrm{O}_{3} \text { in ore } \ldots \ldots \ldots \ldots \ldots \\
\text { Percent of chromite in ore } \ldots \ldots \ldots\end{array}$ & $\begin{array}{l}34.99 \\
99\end{array}$ & $\begin{array}{l}2.73 \\
43.4 \\
75\end{array}$ & $\begin{array}{l}1.88 \\
47.4 \\
98\end{array}$ & $\begin{array}{l}1.78 \\
46.9 \\
97\end{array}$ \\
\hline
\end{tabular}

43. Chromite from recrystallized ore, deposit No. 1, Red Mountain. No. 1.

44. Chromite from normal ore, from unal tered inclusion in dike, deposit

45. Chromlte from high-grade ore, deposit No. 10, Red Mountain.

46. Chromite from high-grade ore, deposit No. 6, Claim Point. 
Each of the three abnormal ores is characterized by an almost complete absence of gangue material and by a high luster which contrasts with the duller appearance of the normal ore. Sample 43 represents ore derived from normal ore like 44 by the addition of $\mathrm{Al}_{2} \mathrm{O}_{3}, \mathrm{Fe}_{2} \mathrm{O}_{3}$, and $\mathrm{FeO}$ during recrystallization caused by the intrusion of augite-hornblende dikes which intersect a band of disseminated ore. The dikes contain bands of very heavy, lustrous, slightly magnetic chromite along their lower contacts which was concentrated from the disseminated ore and changed in composition. (See p. 165.) Sample 45 is from an ore body (see p. 170) that cuts across the normal banding at a small angle. The ore represented by 46 is normal in attitude but not in appearance.

The only prominent mineral other than chromite in the normal deposits is olivine, or serpentine derived from it. Kammererite, the lavender-colored chrome-chlorite, and uvarovite, the green chrome-garnet, are frequently found on joint surfaces. Spectrographic analysis showed a platinum content of 0.02 troy ounces per ton of chromite concentrate for sample 44, and none for samples 43,45 , and 46 .

The average size of the grains in the disseminated ore is less than 1 millimeter in diameter. Crystal faces are not ordinarily visible to the naked eye, but in thin section straight edges and sharp angles are commonly seen. Grains occur singly, or in irregular aggregates with interstitial olivine. A few examples of nodular ore were seen,' but there are no deposits in which it is important. Chromite forms 70 percent or more of the high-grade bodies.

\section{Concentration of low-grade ores}

The high content of $\mathrm{Cr}_{2} \mathrm{O}_{3}$ and the favorable chrome-iron ratio of the pure chromite mineral should make concentration of the disseminated ores practicable. However, the small grain 
size and rather fresh olivine gangue will introduce difficulties The fine grinding necessary to liberate the chromite may cause a considerable amount of sliming, as chromite is very brittle. The small difference in specific gravity between the chromite and the olivine--the former being about 4.4 and the latter 3.3-suggests that gravity concentration might be unsatisfactory, and this impression is confirmed by the results of the following test, made by H. A. Doerner $11 /$ of the Bureau of Mines. Ore from Claim Point assaying 29.5 percent of $\mathrm{Cr}_{2} \mathrm{O}_{3}$, presumably from deposit No. I or No. 10, was used. The procedure and results may be summarized as follows: After breaking the ore in a jaw crusher and passing it through rolls until it was all minus 40 mesh, the material was classified with 90 and 150 mesh screens. Tabling of these fractions. Into concentrates, middlings, and tallings, and reworking of the middlings, gave a composite product containing 50 percent of $\mathrm{Cr}_{2} \mathrm{O}_{3}$ and representing 66 percent of the total $\mathrm{Cr}_{2} \mathrm{O}_{3}$ in the ore. The tailings contained 16.4 percent of $\mathrm{Cr}_{2} \mathrm{O}_{3}$.

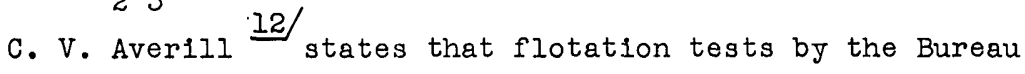
of Mines at the Mississippi Valley Experiment station in Rolla, Missouri, gave a product that contained 56.35 percent of $\mathrm{Cr}_{2} \mathrm{O}_{3}$ and represented 89.7 percent recovery from ore assaying 32.17 percent of $\mathrm{Cr}_{2} \mathrm{O}_{3}$. This ore, from the Selad Creek deposit in northern California, is simllar in grade and occurrence to the

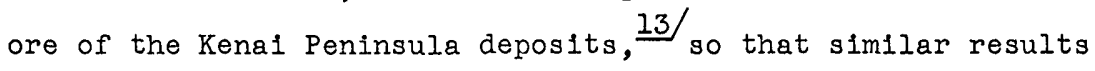
should be possible with the Alaskan ore.

11/ Doerner, H. A., Concentration of Chrom1te: U. S. Bur. Mines Rept. Inv. 3049, 1930.

12) Averill, C. V., Mines and mineral resources of Siskiyou County: Callfornis Jour. Mines and Geology, vol. 31, No. 3, pp. 268-269, 1935.

13) Rynearson, G. A., and Smlth, C. T., Chromite doposits in the Selad quadrangle, S1skiyou County, Callfornia: U. S. Geol. Survey Bull. 922-J, pp. 289-291, 1940. 


\section{Origin}

The ore bodies were formed by the segregation of chromite grains which crystallized out of the magma at an early stage. The method of concentration of the grains is not clearly understood, but may have been by the sinking of early formed chromite grains in the lighter silicate melt. The tabular shape of the ore bodies could possibly have been caused by settling to a solid floor, but a rhythmic precipitation that would give rise to the very thin bands of chromite and olivine is difficult to explain. The fine banding suggests flow structure. A combination of sinking and flow seems to be the most probable mode of formation. The pyroxenite bands almost certainly originated in the same manner as the chromite bands, for they have the same structures, occur both above and below the ore bands, and are everywhere parallel to them.

As the ore bodies were not formed by solutions coming up from great depth, but by local concentration in a cooling magma, it is reasonable to assume that the vertical extent of the deposits does not greatly exceed the horizontal length. The bodles exposed at present are simply those laid bare by erosion. There are almost certainly other ore bodies that are not yet exposed, and there were others that have been eroded away. However, the prospect of finding buried ore bodies seems slight, since they are undoubtedly scattered without system in the dunite and form only a very small percentage of the total mass of the rock.

Chromite is unaffected by normal weathering processes, and there has been no leaching or enrichment of the deposits.

\section{ORE RESERVES}

The estimates given below of tonnage of chromite available on the Kenai Peninsula have been computed from measurements of 
dimensions exposed at the surface, with an arbitrary assumption for the depth of each deposit. This assumption is made necessary because very little underground work has been done. The method used is essentially that of Gill. $\frac{14 /}{\text { It }}$ is based on the probability that the dip length was originally about the same as the strike length, and that, on the average, half of each body has been eroded away. Therefore a depth of half the present exposed length is used, with the full realization that the estimates may vary widely from the true tonnages. The estimates are given in long tons, whereas Gill's were in short tons.

Channel samples were cut across most of the larger deposits to determine the grade of the ore. The analyses were made in the chemical laboratory of the Geological survey in Washington, D. C. For deposits that were not sampled an estimate of grade has been made from the appearance and weight of the ore.

The dividing line, with regard to tenor, between shipping and concentrating ore will depend upon the price and the grade required at the time of mining. For this report the line is placed at 40 percent of $\mathrm{Cr}_{2} \mathrm{O}_{3}$. Although 48 percent is now required, ore as Iow as 30 percent was accepted in 1918, and it is probable that the standards would be lowered again in any emergency that made it worth while to mine this ore. The minimum percentage for concentrating ore is even more problematical, as increased efficiency in milling methods should result in a steady lowering in the requirements for $\mathrm{Cr}_{2} \mathrm{O}_{3}$ content of the "heads". However, as there are few large masses of very low grade ore, factors involved in mining nearly all the bodies examined will be accessibility and tonnage.

The reserves available on Kenal Peninsula are estimated at about 150,000 tons, which is subdivided as shown in the accompanying table. No allowance has been made for fallure to recover

14/ G111, A. C., op. c1t. (BuIl. 742), p. 28. 
all the chromite in the concentrating ore, so that the figures for this item are greater than would be realized in actual operation. In calculating the reserves a number of the small occurrences have been omitted, but they probably will not affect the total materially.

\begin{tabular}{l|r|r|r|r}
\multicolumn{2}{c}{ Chromite reserves, in tons, on Kena1 Peninsula, Alaska } \\
\hline Area & $\begin{array}{r}\text { Chromite in } \\
\text { shipping ore }\end{array}$ & $\begin{array}{c}\text { Concentrat- } \\
\text { ing ore }\end{array}$ & $\begin{array}{r}\text { Chromite in } \\
\text { concentrat- } \\
\text { ing ore }\end{array}$ & $\begin{array}{r}\text { Total } \\
\text { chromite }\end{array}$ \\
\hline Claim Point....... & 5,600 & 58,450 & 26,500 & 32,100 \\
Red Mountain..... & 67,500 & 112,250 & 51,000 & 118,500 \\
\hline & 73,100 & 170,700 & 77,500 & 150,600 \\
\hline
\end{tabular}

Two deposits, the Star No. 4 at Red Mountain and the Bluff at Claim Point, are estimated to contain 42 and 19 percent respectively of this total, the remaining 39 percent being divided among twenty deposits. Plans for development must center on the principal deposits, the others being regarded as supplementary reserves. Although the Kenal Peninsula deposits probably cannot compete successfully in the open, world-wide market, they should be an important source of chromite if foreign trade is cut off, because of their high content of $\mathrm{Cr}_{2} \mathrm{O}_{3}$ and their favorable chrome-iron ratio.

\section{MINES AND PROSPECTS}

\section{Claim Point}

Claim Point, which is nearly surrounded by water, is easily accessible, as ships can come in fairly close to shore. Active mining operations would require the construction of a new wharf, mill, and living quarters. Timber is fairly plentiful on the point and along the shores of Port Chatham. There is no good supply of fresh water on the point, but several streams enter the north side of Chrome Bay, and an ample supply for concentrating could be obtained with a small dam and 4,000 feet of pipe. No pumping should be necessary. 
An unusual and important feature of cook Inlet is the height of the tides, which regulate all activity on the water and must continually be taken into account. The extreme range in water level at Claim Point is about 23 feet. The map, (pl. 25), shows the approximate high-tide mark, but at low tide it was possible to map some distance out from "shore"; nearly half the exposed bedrock, indeed, is below high-tide level. Several ore bodies are exposed in this littoral zone which can be worked only at low tide, if at all.

\section{Claims}

All the mining claims at Claim Point are held by Lass and Whitney, either directly or through F. A. Rapp. One claim, the Bluff No. 1, is patented. This claim and the Bluff No. 2, which adjoins it on the southeast, have been indicated on plate 25. The stakes for the other cla1ms were not seen, but clalm notices show that the Reef mine, No. 1, is covered by one claim extendIng parallel to the strike and by another running perpendicular to it, joining the Bluff No. 2 on the north. Another claim, the Bluff No. 3, covers some of the deposits along the west shore of the point.

\section{Deposits}

The numbers assigned to the deposits are those used by Gill in Bulletin 742 except that his No. 8 is considered as two separate bodies. Estimated chromite reserves at Claim Point are shown in the table on page 158. Possible tonnages below lowtide level have been omitted.

No. 1, Reef mine.--The Reef mine, (flg. 12), is 400 feet southeast of Claim Point on a rocky islet which is connected with the mainland at low tide and almost under water at high tide. The deposit at this mine has furnished nearly all the chromite that has been shipped from Alaska. It consists of two parallel lenses, which are in contact with each other at one point, and which have been faulted considerably. The exposed length of the northern lens is 150 feet, that of the southern lens 110 feet. Each is from 20 to 25 feet wide in the center and tapers toward the ends. Both strike N. $80^{\circ}-85^{\circ} \mathrm{E}$. and dip steeply south. The principal faults strike approximately north 
Chromite reserves, in tons, at Claim Point

\begin{tabular}{|c|c|c|c|c|}
\hline $\begin{array}{c}\text { Ore body No. } \\
\text { on pl. } 25\end{array}$ & $\begin{array}{l}\text { Chromite in } \\
\text { shipping ore }\end{array}$ & $\begin{array}{c}\text { Concentrat- } \\
\text { ing ore }\end{array}$ & $\begin{array}{l}\text { Chromite in } \\
\text { concentrat- } \\
\text { ing ore }\end{array}$ & $\begin{array}{l}\text { Total } \\
\text { chromite }\end{array}$ \\
\hline $\begin{array}{l}1 \ldots \ldots \ldots \\
7 \ldots \ldots \ldots \\
8-\AA \ldots \ldots \\
8-B . \ldots \ldots \\
10 \ldots \ldots\end{array}$ & 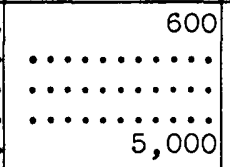 & $\begin{array}{r}1,100 \\
1,350 \\
1,100 \\
1,900 \\
53,000\end{array}$ & $\begin{array}{r}700 \\
550 \\
450 \\
800 \\
24,000\end{array}$ & $\begin{array}{r}1,300 \\
550 \\
450 \\
800 \\
29,000\end{array}$ \\
\hline & 5,600 & 58,450 & 26,500 & 32,100 \\
\hline
\end{tabular}

1) Abore low-tide level.

and dip gently to steeply eastward. The displacement has been largely vertical, although on the southern body there has been a southward shift of the east blocks. There are also minor offsets of the north lens on faults striking about $\mathrm{N} .75^{\circ} \mathrm{E}$. and dipping $50^{\circ}$ to $75^{\circ} \mathrm{S}$. The faults are commonly marked by streaks of crushed and slickensided chocolate-brown chromite.

In tenor the ore varies from massive black chromite to thin bands of grains disseminated in the dunite. A l-foot dike of dunite and dikelets with bright-green chrome diopside (?) cut across the banded ore and dunite at small angles.

Channel samples were taken across the ore body in three places. Samples 1 to 3 were cut from north to south across the center of the north lens, 5 and 6 across this lens 30 feet to the west, 4 across the south lens on the line of 1-3, and 7 to 9 across the south lens 40 feet east of 4 .

Analyses of channel samples from the Reef mine, Claim Point [R. E. Stevens, analyst]

\begin{tabular}{|c|c|c|c|c|c|c|}
\hline \multirow[b]{2}{*}{$\begin{array}{l}\text { Sample } \\
\text { No. }\end{array}$} & \multirow[b]{2}{*}{$\left|\begin{array}{l}\text { Length } \\
\text { (feet) }\end{array}\right|$} & \multicolumn{2}{|l|}{ Ore } & \multicolumn{3}{|c|}{ Concentrate } \\
\hline & & $\underset{(\text { percent) }}{\mathrm{Cr}_{2} \mathrm{O}_{3}}$ & $\begin{array}{l}\text { Chromite } \\
\text { (percent) }\end{array}$ & $\begin{array}{c}\mathrm{Cr}_{2} \mathrm{O}_{3} \\
\text { (percent) }\end{array}$ & $\underset{\text { (percent) }}{\mathrm{FeO}}$ & $\mathrm{Cr}: \mathrm{Fe}$ \\
\hline $\begin{array}{l}1 \ldots \ldots \\
2 \ldots \ldots \\
3 \ldots \ldots \\
4 \ldots \ldots \\
5 \ldots \ldots \\
6 \ldots \ldots \\
7 \ldots \ldots\end{array}$ & $\begin{array}{l}3.3 \\
7.0 \\
4.0 \\
7.5 \\
5.0 \\
8.0 \\
6.4 \\
4.5 \\
2.9\end{array}$ & $\begin{array}{l}35.8 \\
39.8 \\
40.0 \\
36.5 \\
37.5 \\
43.8 \\
31.9 \\
12.4 \\
47.6\end{array}$ & $\begin{array}{l}66 \\
72 \\
71 \\
65 \\
68 \\
80 \\
55 \\
22 \\
83\end{array}$ & $\begin{array}{l}54.2 \\
55.5 \\
56.0 \\
56.2 \\
55.6 \\
54.9 \\
56.8 \\
56.0 \\
57.6\end{array}$ & $\begin{array}{l}16.5 \\
15.9 \\
15.5 \\
14.0 \\
15.3 \\
12.6 \\
12.7 \\
18.8 \\
14.6\end{array}$ & $\begin{array}{l}2.9: 1 \\
3.1: 1 \\
3.2: 1 \\
3.5: 1 \\
3.2: 1 \\
3.8: 1 \\
3.9: 1 \\
2.6: 1 \\
3.5: 1\end{array}$ \\
\hline
\end{tabular}

1) Total Iron as Feo.

The ore has been mined by open cuts to depths of from 5 to 20 feet below high-tide level. The amount of ore remaining above low tide is comparatively small. There is undoubtediy a larger amount below that level, but its recovery would be difficult and expensive, for only a few square yards of the islet, upon which to base operations, remain above high water. Either a shaft or extensive coffer dams would be required, and the jointed and faulted nature of the deposit makes it doubtful whether water could be kept out of the workings. 


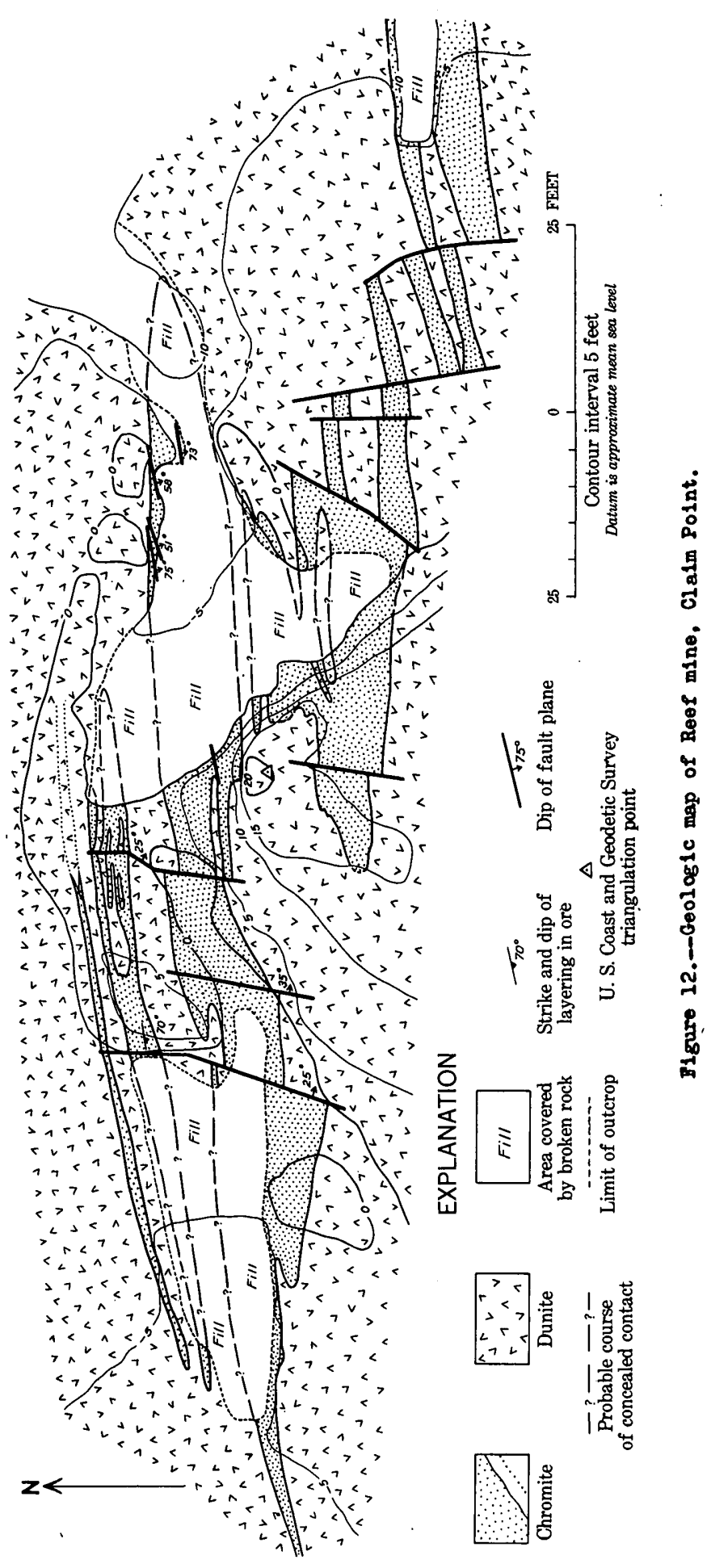


No. 2.--About 50 feet east-northeast of the new log cabin on the southeast shore of the point there is a small deposit of chromite. It is a streak about 18 inches wide and 50 feet long, with a strike of $\mathrm{N}$. $77^{\circ} \mathrm{E}$. and a dip of $80^{\circ} \mathrm{S}$. It pinches out at the east end, and frays out into the dunite to the west. Some of the ore is probably of shipping grade.

Nos. 3 and 4.--Two faulted lenses of chromite are exposed in the high cliff on the northeast side of the point. They are inaccessible, but talus blocks on the beach show the ore to be of the banded, disseminated type. The ore occurs in two nearly parallel layers, the larger band of which is 3 to 4 feet thick, and was estimated to extend 40 feet vertically up the cliff. The ore has been offset along nearly horizontal faults. The upper blocks have moved north with respect to the lower blocks, the displacement being from 2 to 15 feet.

No. 5.--The base of what may once have been a fairly large ore body is exposed in the low cliff 100 yards north of Nos. 3 and 4. A horizontal fault separates a few narrow, vertical streaks of chromite, which pinch out downward, from an overlying body of low-grade banded ore 15 feet wide, which dips about $70^{\circ}$ $\mathrm{S}$. The ore is badly fractured, and serpentine slickensides are common on the joints. As the fault is only a short distance below the top of the cliff, it appears unlikely that any considerable mass of ore remains. Lack of exposures made it impracticable to trace the ore inland.

No. 6.--About 150 feet east-northeast of No. 5 a small ore body which strikes $N .86^{\circ} \mathrm{W}$. and dips vertically is exposed at low tide. The ore appears to be high grade, but analys is 46 , page 151, shows that it is composed of a chromite low in $\mathrm{Cr}_{2} \mathrm{O}_{3}$. The principal lens is 20 feet long, with a maximum width of 26 inches and an average of 20. At each end it narrows to thin stringers which continue for 20 feet or more. Narrow bands and small lenses lie parallel to the larger body for several feet to the north. To the east the stringers are covered by sand. The ore lies in a shallow trough worn by wave action in the chromite, which is less resistant to abrasion than the dunite.

No. 7.--On the northeast slope of Claim Point hill, at an altitude of about 200 feet, 150 yards west of the cliff, there are several small prospect trenches. The southernmost of these is on a body of banded, disseminated ore estimated to contain about 20 percent of $\mathrm{Cr}_{2} \mathrm{O}_{3}$. The width of the ore is 13 feet at the face of the cut and lo feet at the mouth, which is 37 feet northeast. The layers strike N. $65^{\circ} \mathrm{E}$. and dip $70^{\circ} \mathrm{SE}$. The ore is not exposed to the southwest or northeast.

No. 8.--Forty feet to the north a trench 20 feet long by 10 feet wide exposes 9 feet of ore similar to that at No. 7 . The layers strike N. $72^{\circ} \mathrm{E}$. and dip $85^{\circ} \mathrm{SE}$. The ore becomes narrower northeastward within the length of the trench, and only scattered stringers of chromite crop out 30 feet farther along the strike. To the southwest the ore fans out into widely separated stringers in an outcrop 35 feet long.

Another open cut, 125 feet west of this trench, exposes a width of 17 feet of banded ore of the same type, striking N. $67^{\circ}$ $E$. and dipping $88^{\circ} \mathrm{SE}$. The length exposed is 20 feet. Twenty feet farther to the northeast only a few stringers are seen, and there are no exposures to the southwest. 
Gill $15 /$ belleved that both trenches are on a single ore body that has been offset. The writer thinks, on the contrary, that each is on a small individual body, because the easterly bands are seen to break up and diminish in thickness and tenor to the southwest. In accordance with this view, the eastern body has been designated as 8-A and the western as 8-B. Estimates of tonnage have been computed separately.

No. 10.--The Bluff No. I ore body, (see fig. 13), the largest known at Claim Point, is about 500 feet west of No. 8 , at an altitude of 150 feet. It is 400 feet south-southwest of the remains of the old mill, built in 1918 to concentrate the ore. Development work on the ore includes an adit extending 33 feet Into the ore body, several trenches across the ore, and a large exposure made by stripping off all the cover from an area 100 feet long and 50 feet wide. This work is sufficlent to show

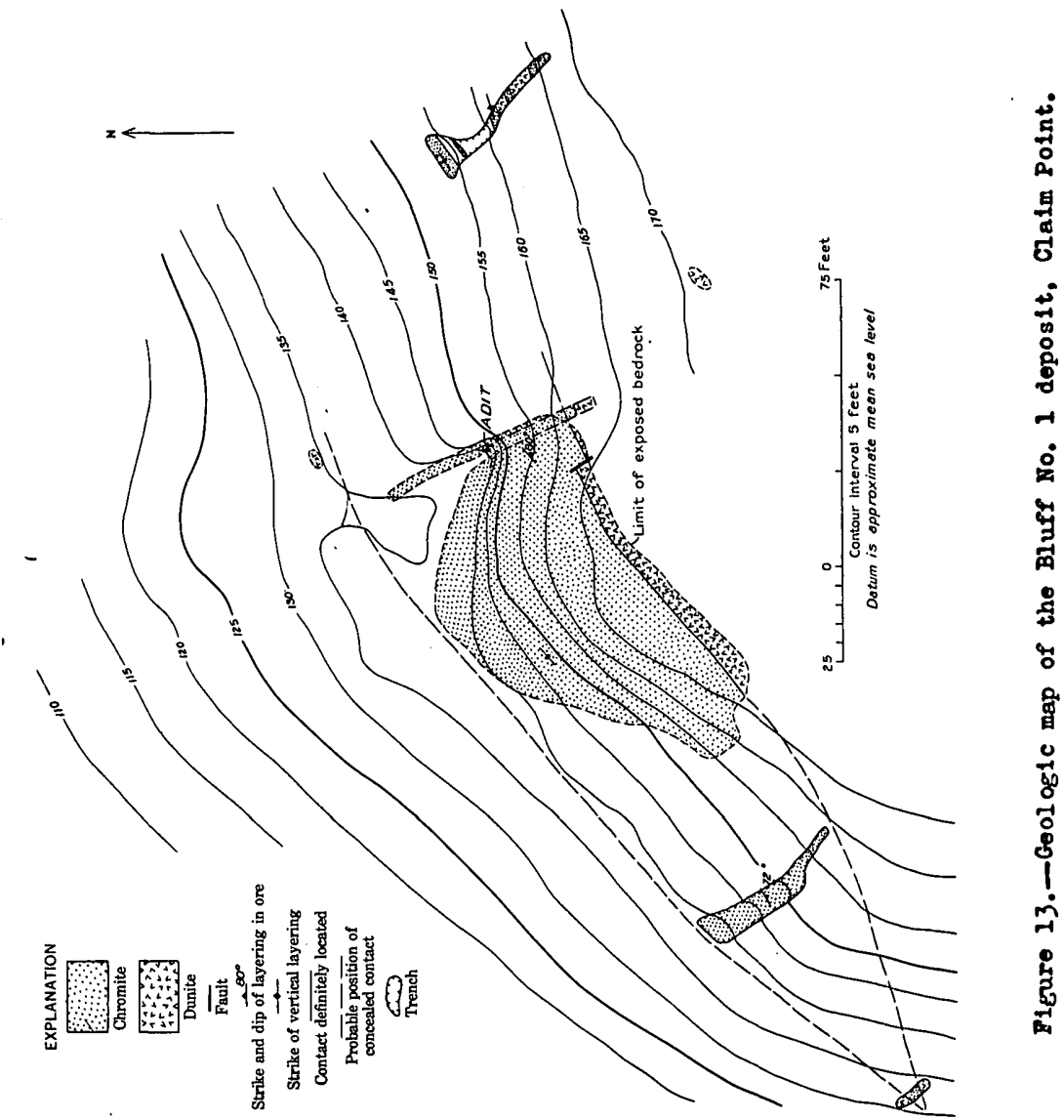

that the body is at least 200 feet long and at least 50 feet wide near the adit. The southeastern boundary of the ore body is definitely located; the northwestern boundary has not been uncovered but probably lies close to the limit of the stripped area. 
The presence of faults is revealed by slickensided surfaces in the adit and by an of 'set of the south contact. It is not known whether there are any major faults that might limit the ore or cause difficulty in following it. Gill 16/has suggested that the Bluff ore body and Nos. 7 and 8 , and perhaps even Nos. 3 and 4 , may originally have been part of a single body that has been offset by large-scale f'aulting. While this seems very unlikely, the possibility must be considered in estimating the tonnage of ore of the property, and any f'urther development work should have the determination of this point as one of its goals.

A channel was cut across the ore body 60 feet southwest of the adit. Samples were taken successively from the southeast contact to the northwest. The results indicate that some shipping ore should be available, but that most of the material will require concentration.

Analyses of channel samples from the Bluff No. I deposit, Claim Point

[R. E. Stevens, analyst]

\begin{tabular}{|c|c|c|c|c|c|c|}
\hline \multirow[b]{2}{*}{$\begin{array}{c}\text { Sample } \\
\text { No. }\end{array}$} & \multirow[b]{2}{*}{$\left|\begin{array}{l}\text { Length } \\
\text { (feet) }\end{array}\right|$} & \multicolumn{2}{|l|}{ Ore } & \multicolumn{3}{|c|}{ Concentrate } \\
\hline & & $\begin{array}{c}\mathrm{Cr}_{2} \mathrm{O}_{3} \\
\text { (percent) }\end{array}$ & $\begin{array}{l}\text { Chromite } \\
\text { (percent) }\end{array}$ & $\begin{array}{c}\mathrm{Cr}_{2} \mathrm{O}_{3} \\
\text { (percent) }\end{array}$ & $\begin{array}{c}\mathrm{FeO}^{\mathrm{I}} \\
\text { (percent) }\end{array}$ & $\mathrm{Cr}: \mathrm{Fe}$ \\
\hline $\begin{array}{l}10 \ldots . . \\
11 \ldots . . \\
12 \ldots \\
13 \ldots \ldots \\
14 \ldots \ldots \\
15 \ldots \ldots\end{array}$ & $\begin{array}{l}6.2 \\
6.6 \\
5.8 \\
8.2 \\
7.0 \\
6.4 \\
7.4\end{array}$ & $\begin{array}{l}46.4 \\
21.5 \\
25.6 \\
40.0 \\
32.3 \\
13.7 \\
21.9\end{array}$ & $\begin{array}{l}79 \\
37 \\
44 \\
67 \\
55 \\
24 \\
38\end{array}$ & $\begin{array}{l}58.8 \\
58.0 \\
58.6 \\
59.4 \\
59.0 \\
57.7 \\
57.9\end{array}$ & $\begin{array}{l}15.5 \\
16.5 \\
14.2 \\
12.8 \\
15.6 \\
18.9 \\
17.6\end{array}$ & $\begin{array}{l}3.3: 1 \\
3.1: 1 \\
3.6: 1 \\
4.1: 1 \\
3.3: 1 \\
2.7: 1 \\
2.9: 1\end{array}$ \\
\hline
\end{tabular}

1) Total iron as $\mathrm{FeO}$.

No. 11.--On the western shore of the point, nearly 2,000 feet from No. 10, there is a long exposure of dunite, partly covered at high tide. At a number of places there are small lenses and narrow streaks of chromite. The lenses are from 6 to 10 Inches thick and a few feet long. Nothing was seen that appeared to offer possibilities for mining.

No. 12.--On the south shore of the point, about 2,000 feet west of the cabin, there are three groups of low-grade stringers within 200 feet. The easternmost of these consists of 12 feet of low-grade, banded chromite and dunite, with 1 foot in the center which appears to be of good concentrating grade. The exposed length is 25 feet, but beach sand covers the ore at each end. The layering strikes $N .40^{\circ}$ E. and is vertical. A 20-foot zone 140 feet to the northwest contains narrow chromite bands exposed for a length of 20 feet. Two separate layers, both about 1 foot wide, were estimated to contain 20 to 25 percent of $\mathrm{Cr}_{2} \mathrm{O}_{3}$. Fifty feet west another zone of low-grade stringers, parts of which might be workable, is exposed for a width of 20 to 30 feet. The stringers strike N. $50^{\circ} \mathrm{E}$. and are vertical; they are offset by many small faults.

16) Gill, A. C., op. c1t. (Boll, 742), p. 23. 


\section{Red Mountain}

Red Mountain is much more difficult of access than Claim Point. There are no roads to the area and no vehicles or pack animals in the country. All equipment and supplies must be packed in on the backs of men, through rugged country with many steep slopes. (See pl. 29, A.) There has been no mine development or construction except a small log cabin in the valley of Windy River.

The mountain is completely bare of timber, and there is little in Windy River valley, but Jakolof Creek valley is heavily forested. Water is plentiful most of the year, the streams being kept full by frequent rains and melting snow. Most of the mountain is free of snow by the first of July, but some of the ore deposits, the Star No. 4 in particular, are not completely exposed until late in August. For this reason exploration and construction should be done during the late summer months. Snow is not likely to interfere much with mining operations after the required installations have been made.

Before mining can begin it will be necessary to bulld a wharf at tidewater, a road into Windy River valley, probably an aerlal tram to an altitude of 1,000 to 2,000 feet up the mountain, a mill, if concentrating ores are to be used, and living quarters. The most practicable route for a road would be down the valley of Windy River to the sharp bend and thence over the low divide to Tutka Bay. Although Port Dick, Rocky Bay, and Seldovia Bay are almost as near the mountain as Tutka Bay, the distribution of most of the deposits inside the large cirque at the head of Windy River makes a road down Windy River valley the best solution of the transportation problem. At present an excellent foot path connects Red Mountain with the head of Jakolof Bay. The chief objection to a road along this route is that Jakolof Bay is too shallow for large ships, so that ore would 
have to be lightered several miles to the mouth of the bay. Tutka Bay, on the contrary, is large and deep. The road-buildIng problems would be approximately the same in either place. Aerial trams appear to offer the best means of transporting material up the steep slopes to the deposits, and of getting the ore down to the valley. Probably two would be needed to reach all the deposits inside the cirque, one up the east and one up the west wall of the valley. The deposits on the outer slopes would be very expensive to mine because of their inaccessibility. A mill, centrally located in the valley, would be required to concentrate the low-grade ore, if maximum production is to be attained. Considerable low-grade material would have to be handled, even though mining is only for a shipping grade of ore. A mill would approximately double the potential production.

\section{Claims}

Twenty-six lode mining claims (see pl. 27) are known on Red Mountain, and there may very likely be more. Lass and Whitney hold the only three patented claims, which were originally staked in 1918. These are the only claims that date back to World War days; all the others were abandoned. Renewed interest during the last few years, particularly during 1940, brought about the staking of the 23 unpatented claims. The patented claims have been surveyed, but the others have been laid out by pace and compass and consequently are not all as regular in shape as represented. Only a few corner monuments were found during the mapping of the area; most claims are based upon the position of the discovery monument plus the description given in the claim notice. The claims to which, in the table below, no ore body is assigned, are staked on small bodies for which no estimate of tonnage has been made, or were staked to cover the possible extension underground of some nearby body. The Rut- 
ledge claims are distinguished by arbitrary numbers, because

their names are not known.

Mining claims on Red Mountain, Alaska

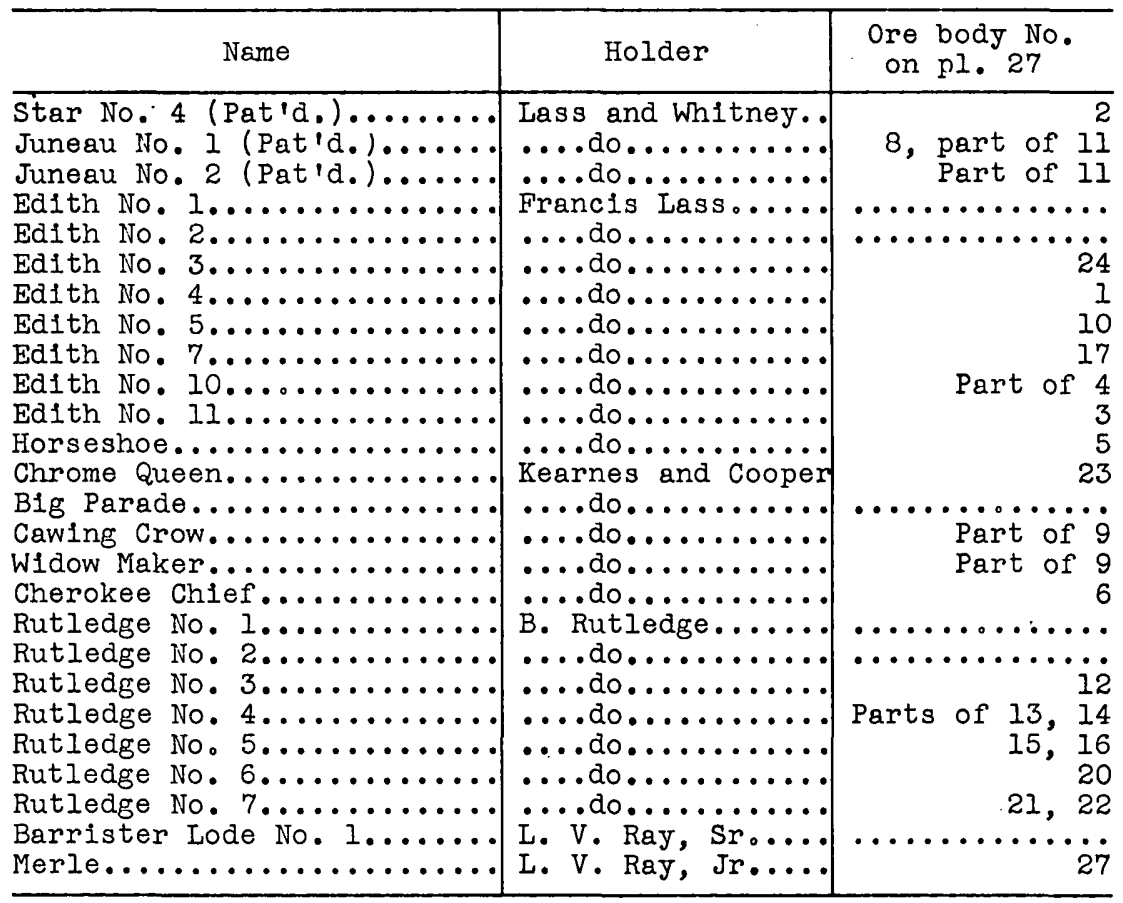

Deposits

Thirty deposits large enough to deserve mention are known at Red Mountain. Gill's system of numbering the ore bodies has been followed so far as it was applicable. His No. 19, which could not be found, has been omitted, but several other deposits have been added to his list. Estimates of reserves are shown in the table on page 166. No estimates of tonnage have been made for certain deposits whose value seems doubtful because of small size, poor exposures, or unfavorable mineralogical character.

No. 1.--One of the deposits on the Edith No. 4 claim, situated 1,500 feet east of Windy River at an altitude of 2,200 feet, is of iltte importance economically, but it is of interest because a 2-foot band of low-grade disseminated ore has been cut by two pyroxene-hornblende dikes, which have engulfed blocks of the ore and changed the composition of the chromite. (See analyses, p. 151.) The layer of ore is about 400 feet long and 2 feet thick, and it strikes N. $10^{\circ} \mathrm{W}$. and dips $70^{\circ} \mathrm{W}$. The two 
Chromite reserves, in tons, at Red Mountain

\begin{tabular}{|c|c|c|c|c|}
\hline $\begin{array}{l}\text { Ore bo } \\
\text { on pl }\end{array}$ & $\begin{array}{l}\text { Chromite } \\
\text { shipping }\end{array}$ & $\begin{array}{c}\text { Concentrat- } \\
\text { ing ore }\end{array}$ & $\begin{array}{c}\text { Chromite in } \\
\text { concentrat- } \\
\text { ing ore }\end{array}$ & $\begin{array}{l}\text { Total } \\
\text { chromite }\end{array}$ \\
\hline$\ldots \ldots \ldots \ldots$ & 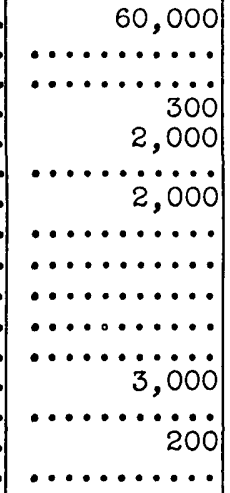 & $\begin{array}{r}8,000 \\
12,500 \\
5,000 \\
600 \\
2,500 \\
10,000 \\
10,000 \\
9,000 \\
20,000 \\
9,000 \\
2,000 \\
1,500 \\
9,000 \\
4,000 \\
650 \\
8,500\end{array}$ & $\begin{array}{r}4,000 \\
5,000 \\
3,000 \\
300 \\
1,500 \\
5,000 \\
4,000 \\
5,000 \\
8,000 \\
4,000 \\
800 \\
800 \\
5,000 \\
1,500 \\
300 \\
2,800\end{array}$ & $\begin{array}{r}64,000 \\
5,000 \\
3,000 \\
600 \\
3,500 \\
5,000 \\
6,000 \\
5,000 \\
8,000 \\
4,000 \\
800 \\
800 \\
8,000 \\
1,500 \\
500 \\
2,800\end{array}$ \\
\hline & 67,500 & 112,250 & 51,000 & 118,500 \\
\hline
\end{tabular}

dikes also strike $\mathrm{N}_{0} 10^{\circ} \mathrm{W}$., but dip $20^{\circ} \mathrm{E}$. Erosion has removed about 175 feet of the center of the body and exposed a good cross-section of the dikes. These are 3 feet thick where they cut the ore band, but they pinch rapidly down the dip, being only narrow stringers 25 feet east. The two dikes converge northward and join near a deep gully, north of which only one dike is seen.

No. 2.--The largest body of high-grade chromite known in the region is on the patented Star No. 4 claim of Lass and Whitney. It is situated at an altitude of 2,600 feet on the comparatively flat area north of Red Mountain. An inclined shaft, Il by 5 feet in cross-section and 6 feet deep, has been sunk near the south end of the ore body, but no other development work has been done.

The ore can be traced almost continuously for over 1,100 feet, but it is only 1 foot thick for more than half this distance. As shown in plate 28, two lenses lie to the north of the large body and apparently are not connected with it although they occur in the same zone. The main ore body is 625 feet long; the ore has an observed maximum thickness of 9.8 feet, and as its middle part is poorly exposed, it may be even thicker. About 500 feet of the ore body is more than a foot thick. The section at the shaft is shown on the following page.

To the south the ore thins and decreases somewhat in tenor until at a point 120 feet south of the shaft it is only l foot thick. Immediately north of the shaft the outcrop is covered, but 250 feet farther north there are three layers which have a total thickness of 5.4 feet. The western boundary of the ore is covered, and a sharp fold makes the total thickness uncertain. The ore continues northward for 200 feet in four bands, which diminish in thickness and tenor until they disappear. Their place is taken by two more bands, the longer one maintaining an average thickness of $I$ foot for 300 feet.

The strike of the layering is $\mathrm{N} .10^{\circ} \mathrm{W}$. and the dip from $70^{\circ}$ to $35^{\circ} \mathrm{W}$., except where minor folding has caused local varia- 


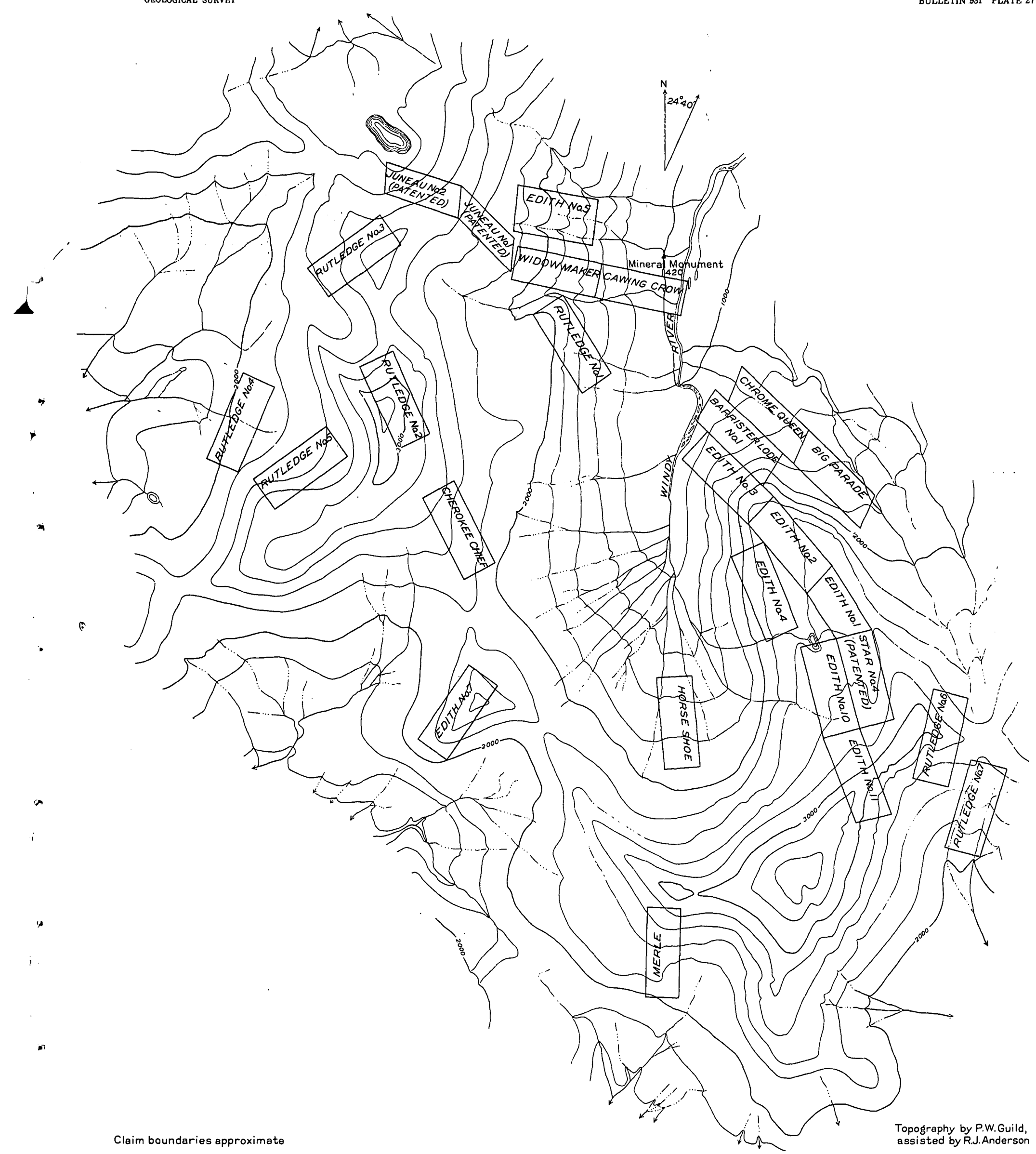

Claim boundaries approximate

MAP SHOWING MINING CLAIMS AT RED MOUNTAIN, ALASKA

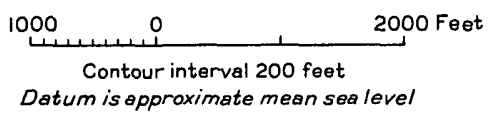

(Eaces p. 166) $4254670-42$ 

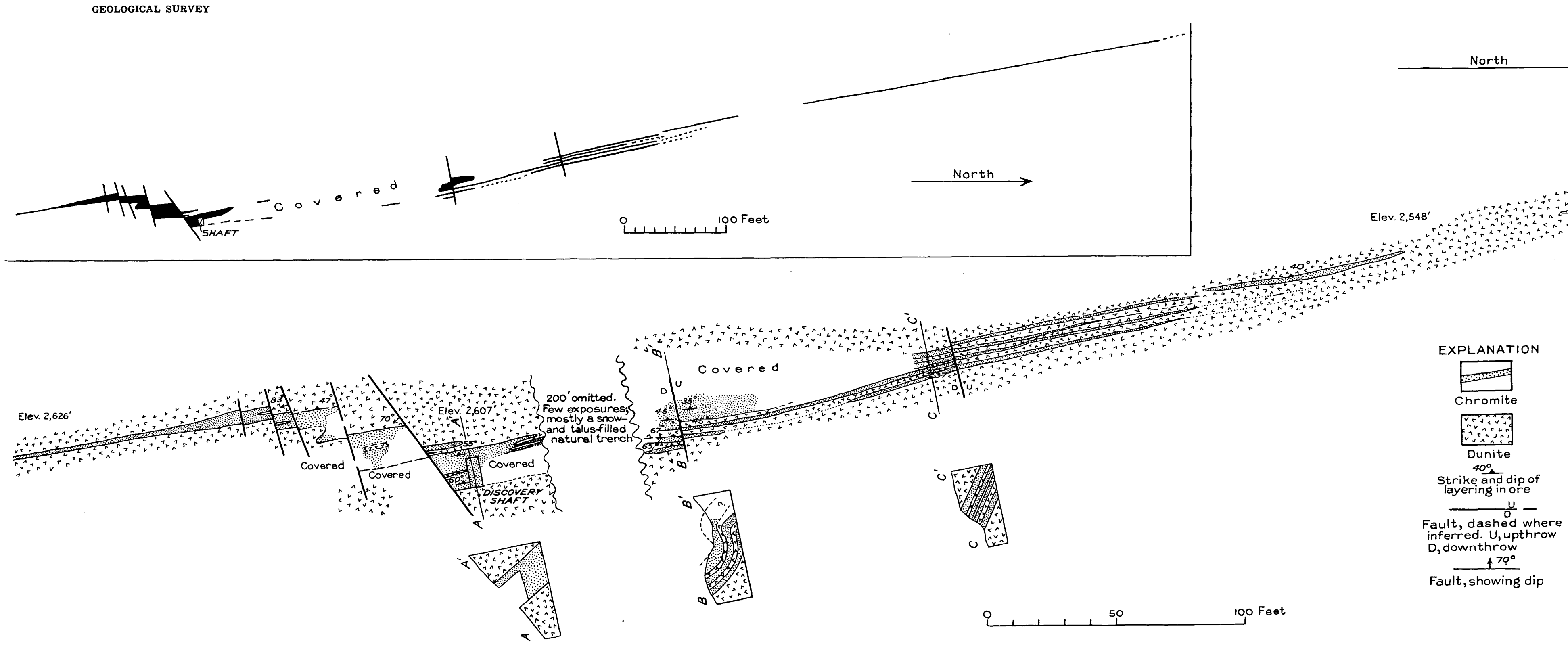

PLAN AND GEOLOGIC MAP OF THE STAR NO. 4 ORE BODY, RED MOUNTAIN, ALASKA 


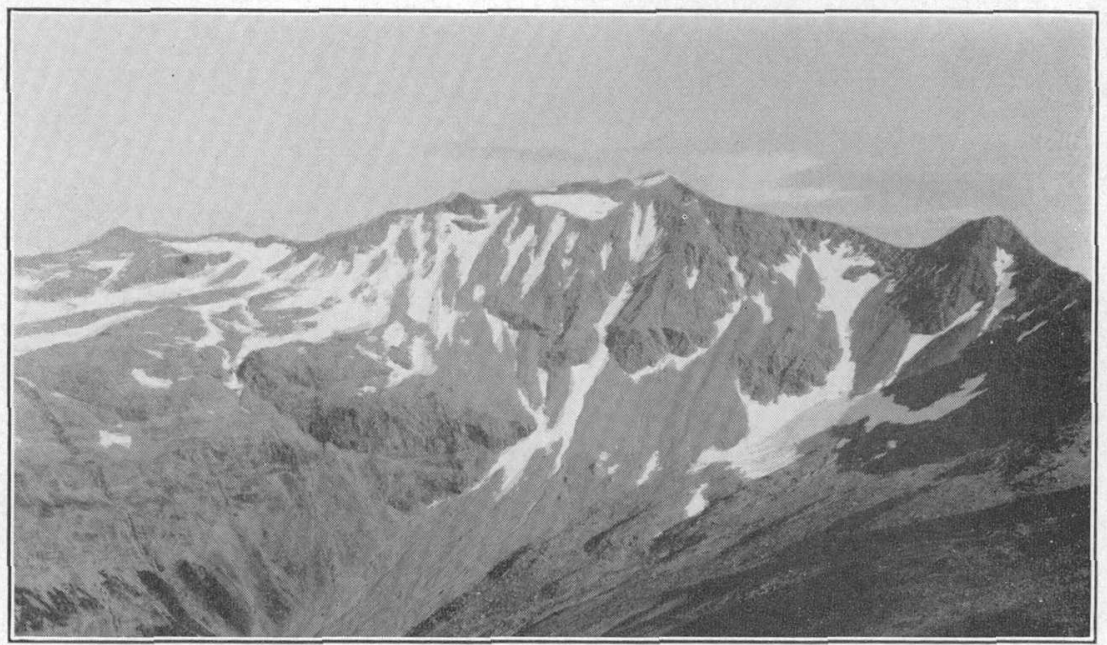

A. VIEW OF RED MOUNTAIN, FROM THE NORTHWEST.

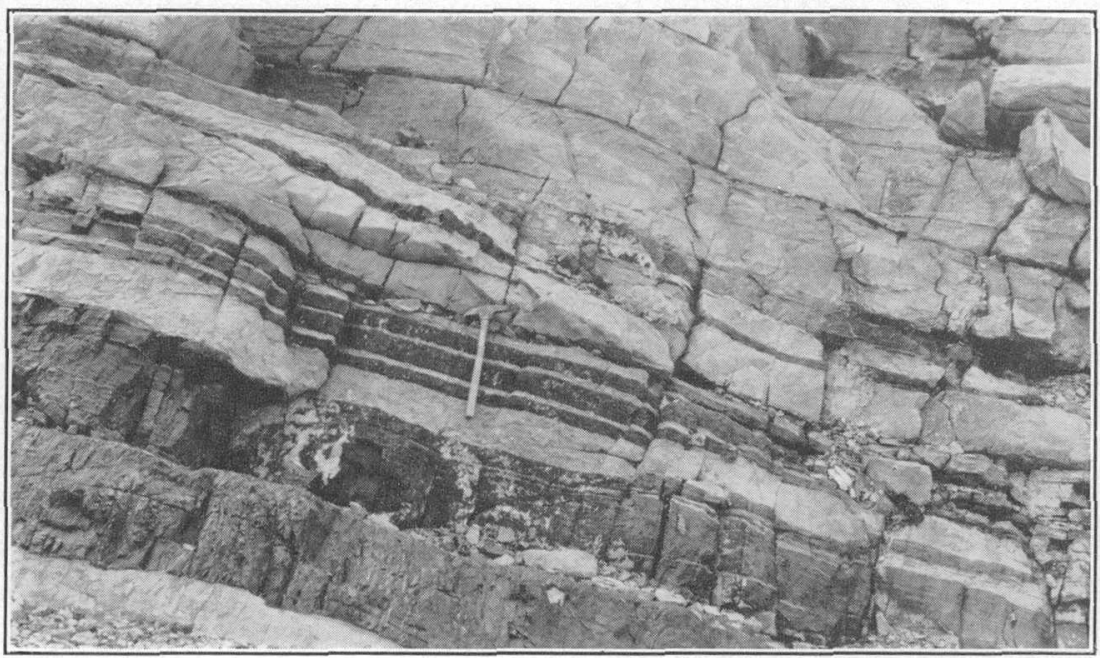

B. BANDED ORE 20 FEET NORTH OF SHAFT, STAR No. 4. 


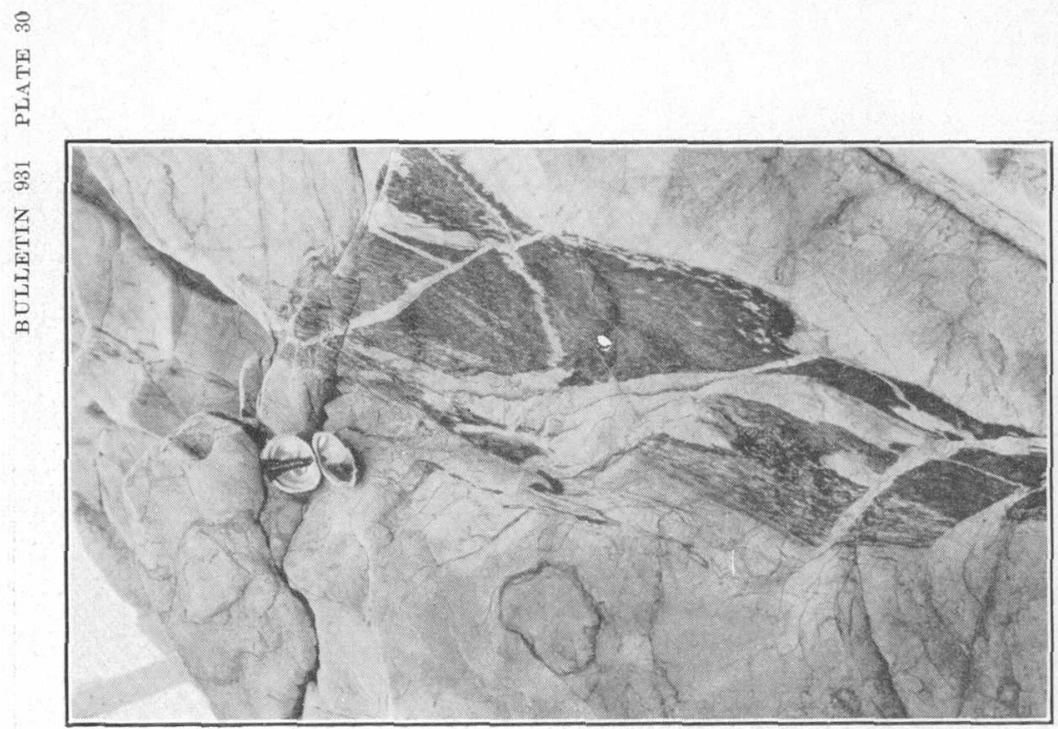

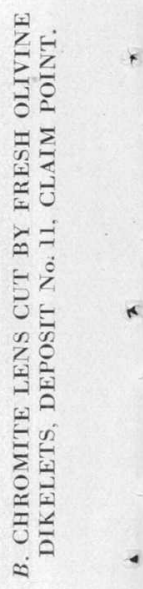

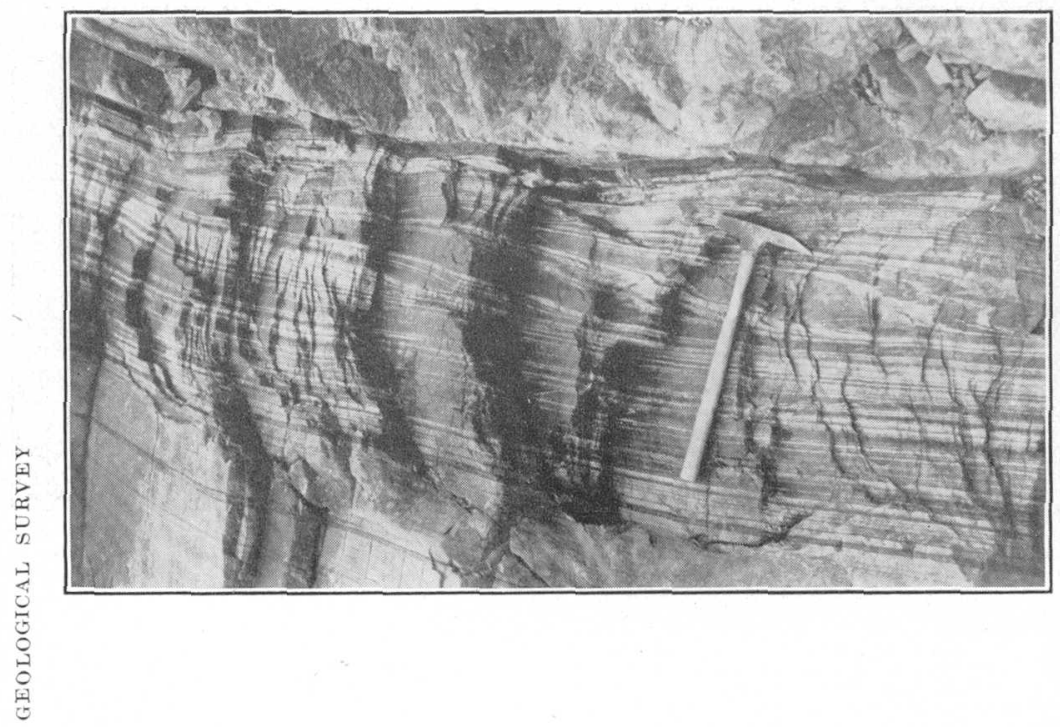

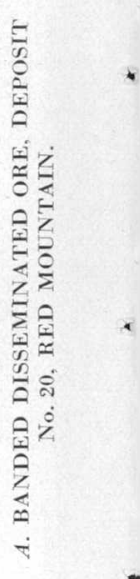




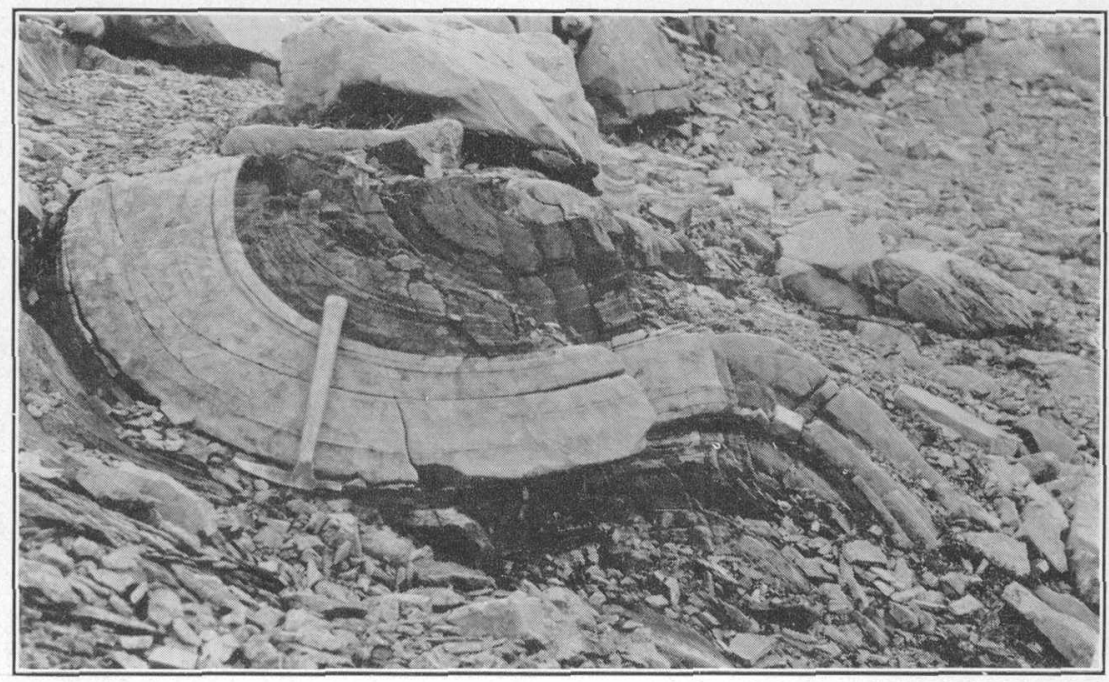

A. DRAG FOLD IN CHROMITE, DEPOSIT No. 24, RED MOUNTAIN.

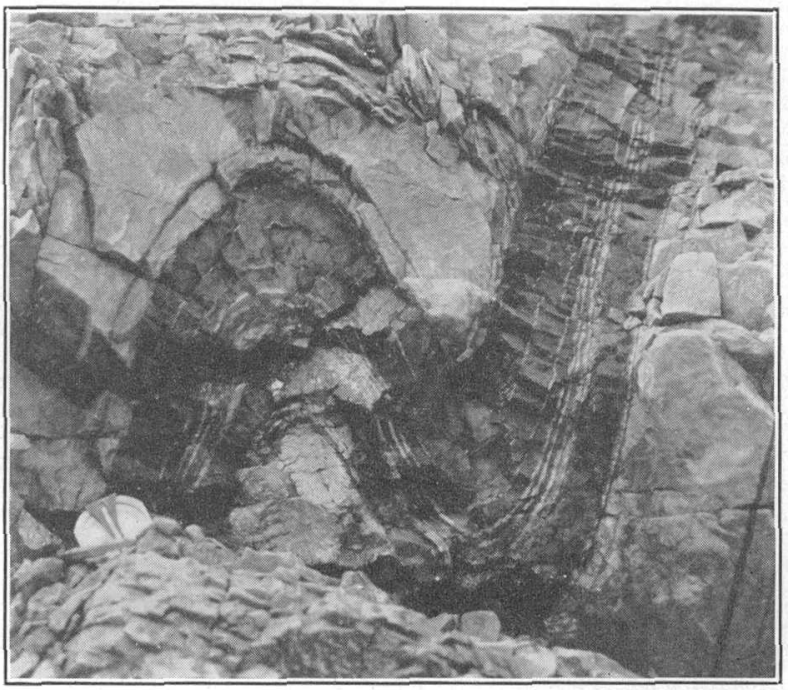

B. DRAG FOLD, DEPOSIT No. 13, RED MOUNTAIN. 
Section along south edge of shaft, Star No. 4, west to east

Barren dunite.

Feet

Chromite with a little olivine gangue............... 0.5

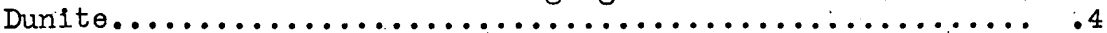

Chromite with a little olivine gangue................. .3

Dunite with a $\frac{1}{2}-1$ ch dikelet of hornblende.................

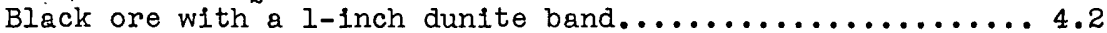

Green hornblende dike, nearly parallel to the banding...... .4

Chromite with four $\frac{1}{2}$ - to 1 -inch dunite bands........... 3.5

Barren dunite................................ 5

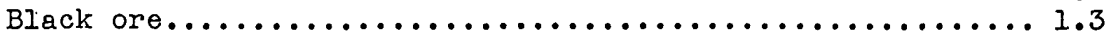

Dunite.

Total thickness $(9.8$ feet is ore $) \ldots \ldots \ldots \ldots \ldots \overline{12.3}$

tions. Seven faults were observed, all striking more or less at right angles to the banding. The greatest offset $1 \mathrm{~s} 12$ feet.

Analyses of channel samples indicate that most of this ore is of good shipping grade. Samples 29 to 31 are from the shaft, 32 and 33 from the section 250 feet north, and 37 to 40 from the section 350 feet north of the shaft. All samples were taken from east to west across the deposit.

Analyses of channel samples from the

Star No. 4 claim, Red Mountain [R. E. Stevens, analyst]

\begin{tabular}{|c|c|c|c|c|c|c|}
\hline \multirow[b]{2}{*}{$\begin{array}{c}\text { Sample } \\
\text { No. }\end{array}$} & \multirow[b]{2}{*}{$\begin{array}{l}\text { Length } \\
\text { (feet) }\end{array}$} & \multicolumn{2}{|l|}{ Ore } & \multicolumn{3}{|c|}{ Concentrate } \\
\hline & & $\begin{array}{c}\mathrm{Cr}_{2} \mathrm{O}_{3} \\
\text { (percent) }\end{array}$ & $\begin{array}{l}\text { Chromite } \\
\text { (percent) }\end{array}$ & $\begin{array}{c}\mathrm{Cr}_{2} \mathrm{O}_{3} \\
\text { (percent) }\end{array}$ & $\begin{array}{c}\mathrm{F} \oplus \mathrm{O} I \\
\text { (percent) }\end{array}$ & $\mathrm{Cr}: \mathrm{Fe}$ \\
\hline $\begin{array}{l}29 \ldots \ldots \\
30 \ldots \ldots \\
31 \ldots \ldots \\
32 \ldots \ldots \\
33 \ldots \ldots \\
37 \ldots \ldots \\
38 \ldots \ldots \\
39 \ldots \ldots\end{array}$ & $\begin{array}{l}1.3 \\
3.5 \\
4.2 \\
1.1 \\
2.8 \\
2.1 \\
1.4 \\
1.1 \\
1.3\end{array}$ & $\begin{array}{l}47.3 \\
47.1 \\
51.0 \\
51.2 \\
52.1 \\
23.9 \\
44.9 \\
50.2 \\
50.6\end{array}$ & $\begin{array}{l}84 \\
82 \\
87 \\
89 \\
90 \\
43 \\
79 \\
85 \\
86\end{array}$ & $\begin{array}{l}56.3 \\
57.7 \\
58.8 \\
57.7 \\
58.2 \\
55.4 \\
56.9 \\
58.8 \\
58.6\end{array}$ & $\begin{array}{l}16.3 \\
14.9 \\
14.8 \\
14.9 \\
14.8 \\
20.8 \\
16.1 \\
14.9 \\
14.6\end{array}$ & $\begin{array}{l}3.0: 1 \\
3.4: 1 \\
3.5: 1 \\
3.4: 1 \\
3.5: 1 \\
2.3: 1 \\
3.1: 1 \\
3.5: 1 \\
3.5: 1\end{array}$ \\
\hline
\end{tabular}

\section{1) Total Iron as $\mathrm{FeO}$.}

No. 3.--A quarter of a mile south of the Star No. 4 a large deposit of low-grade ore crops out on the steep slope and crosses the ridge running north from Red Mountain. The altitude of the outcrop is from 2,900 to 3,100 feet. The ore is thickest at the crest of the ridge, where there is 10 feet of low-grade disseminated chromite in layers which strike $\mathrm{N}$. $10^{\circ} \mathrm{W}$. and dip $30^{\circ} \mathrm{W}$. The bands become narrower and split up down the slope to the west. Talus hides the outcrop east of the ridge, but 300 feet to the south an 18-inch band of ore crops out on the strike of this body and may be the continuation of 1t. The exposed length of the ore is 250 feet. Erosion has removed much of this deposit, and the talus contains much chromite for a quarter of a mile down the slope.

No. 4.--Ore body No. 4 consists of many small chromite lenses in a zone 2,000 feet long and several hundred feet wide, about 800 feet west of the Star No. 4 and parallel to it. These 
lenses are rarely more than a foot thick and 75 feet long. The ore ranges from low-grade, disseminated chromite to shipping ore. The lenses strike N. $20^{\circ} \mathrm{W}$. and dip about $45^{\circ} \mathrm{W}$. Minor folds are common. Dips are often nearly parallel to the rock surface, so that outcrops give the impression that the lenses are thicker than they realiy are. No single body contains much ore, but the total tonnage is estimated to be 3,000 tons of concentrates.

No. 5.--A small ore body crops out at an altitude of 1,750 feet on a glaciated rock projecting through the talus in the cirque at the head of Windy River. Prominent joints perpendicular to the direction of ice movement have facilitated glacial plucking, with the result that the ore is exposed on both horizontal and vertical surfaces. (See fig. 14.) From a practical

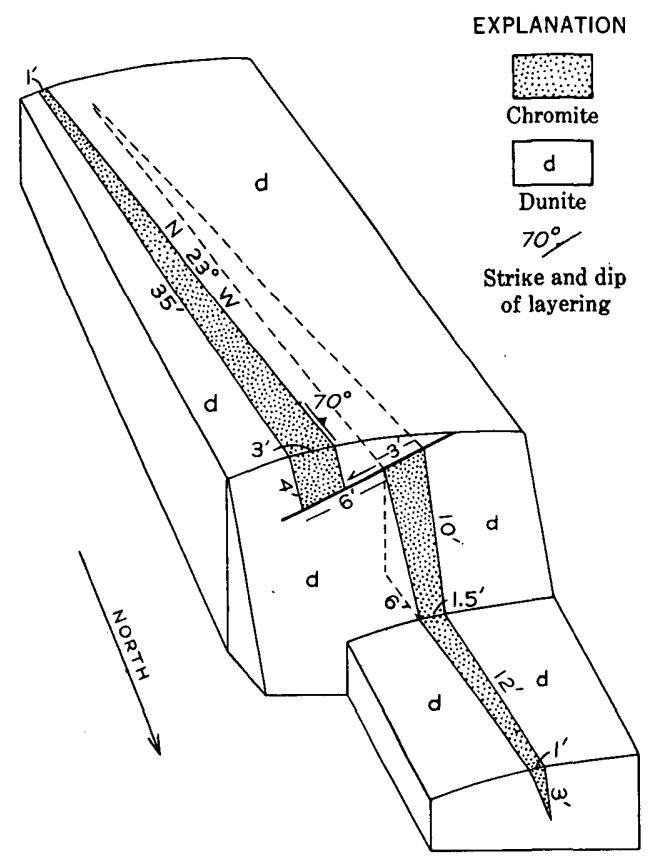

Figure 14.--Block diagram of depos1t No. 5, Red Mounta1n.

standpoint the deposit is unimportant because of its small size. It is a lens 50 feet long, 3 feet across at its widest point, and about 15 feet deep. It consists largely of a good grade of concentrating ore. About 250 feet north-northwest there is an 18-inch band of concentrating ore 50 feet long, which pinches out at. each end. Farther down the slope several still smaller bands are exposed in the stream beds.

No. 6.--Deposit No. 6 is 1,500 feet north of the northern pass between Windy River and Seldovia River, at an altitude of 2,350 feet. Several lenses are distributed along a zone at least 400 feet long, which strikes N. $50^{\circ} \mathrm{W}$. and dips gently southwest into the hillside. The ore crops out just above the top of the talus, and is covered by it in places. The three principal bodies are each 50 or 60 feet long, and from 1 to 3 feet thick. The ore ranges from low grade to shipping grade; most of it is good concentrating ore. 
No. 7.--Seven hundred feet north of No. 6 a very small ore body is exposed at an altitude of 2,500 feet. It appears as a band of high-grade ore a foot wide at the base of the exposure, where it passes under the talus. The strike is $\mathrm{N}_{0} 25^{\circ} \mathrm{W}$.; the dip $45^{\circ}$ SW. The ore tapers upward, and, as Gill points out, if it expands at an equal rate downward there may be a good ore body.

A 12-foot zone of very low grade chromite stringers crops out 50 feet south of No. 7, and the middle 4 feet of 1 t may possibly be rich enough to work. The length of the zone exposed above the talus is only 20 feet.

No. 8.--No. 8 is on the upper bench of the valley at an altitude of 2,250 feet, 3,000 feet west of Windy River, on the patented Juneau No. I claim of Lass and Whitney. A number of shallow trenches have been dug across the ore body, as shown in flgure 15.
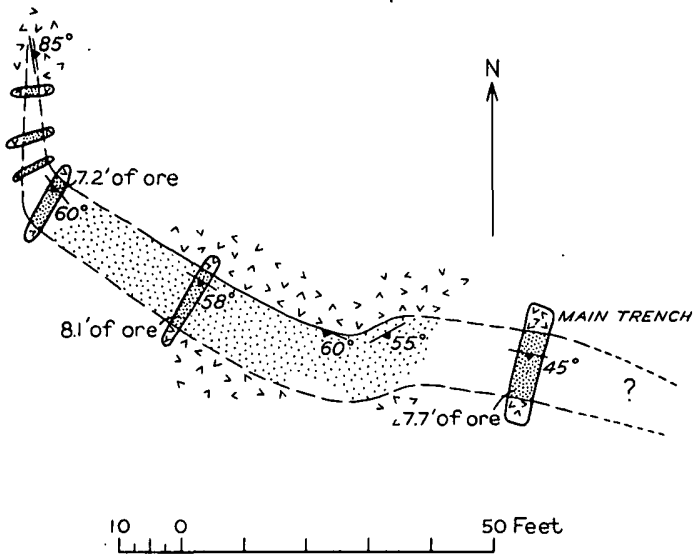

EXPLANATION

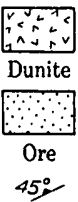

Strike and dip of layering

Boundary of ore

Outline of trench

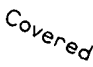

Very low-grade narrow layers of ore

Figure 15. - Sketch map of Juneau No. 1 depos1t, Red Mountain.

The ore has been warped somewhat, causing the strike to range between $\mathrm{S} .60^{\circ} \mathrm{E}$. and N. $60^{\circ} \mathrm{E}$., but 1 ts general trend is $\mathrm{S} .65^{\circ} \mathrm{E}$. The dip ranges from $45^{\circ}$ to $60^{\circ} \mathrm{SW}$. The exposed length is 82 feet, the thickness over this distance is from 7.2 to 8.1 feet. The ore terminates abruptly at the northwest end with a rapid pinching out and a sharp flexure to the north. This was probably caused by faulting that antedated the final consolidation of the dunite. There are no exposures between the main trench and one 95 feet southeast. In this distance 7.7 feet of ore dwindies to a few narrow low-grade bands, and the absence of chromite float in the intervening space indicates that the ore does not extend far southeast of the main trench.

The ore is characterized by a very regular lamination of richer and leaner chromite bands. Channel samples taken at two places across the deposit show the ore to be partly of concentrating and partly of shipping grade. Samples 19 and 20 are from the main trench, 23 and 24 from a trench 53 feet northwest of 1t. (See table on p. 170.)

No. 9.--No. 9 includes several ore bodies which crop out on the steep west wall of the valley a quarter of a mile south of 
Analyses of channel samples from the Juneau No. I claim, Red Mountain

[R. E. Stevens, analyst]

\begin{tabular}{|c|c|c|c|c|c|c|}
\hline \multirow[b]{2}{*}{$\begin{array}{c}\text { Sample } \\
\text { No. }\end{array}$} & \multirow[b]{2}{*}{$\begin{array}{l}\text { Length } \\
\text { (feet) }\end{array}$} & \multicolumn{2}{|l|}{ Ore } & \multicolumn{3}{|c|}{ Concentrate } \\
\hline & & $\begin{array}{c}\mathrm{Cr}_{2} \mathrm{O}_{3} \\
\text { (percent) }\end{array}$ & $\begin{array}{l}\text { Chromite } \\
\text { (percent) }\end{array}$ & $\begin{array}{c}\mathrm{Cr}_{2} \mathrm{O}_{3} \\
\text { (percent) }\end{array}$ & $\begin{array}{c}\text { Fe0 } 1 / \\
\text { (percent) }\end{array}$ & $\mathrm{Cr}: \mathrm{Fe}$ \\
\hline $\begin{array}{l}19 \ldots \ldots \\
20 \ldots \ldots \\
23 \ldots \ldots \\
24 \ldots \ldots\end{array}$ & $\begin{array}{l}3.9 \\
3.8 \\
4.1 \\
4.0\end{array}$ & $\begin{array}{l}44.3 \\
36.3 \\
34.5 \\
43.7\end{array}$ & $\begin{array}{l}75 \\
62 \\
58 \\
73\end{array}$ & $\begin{array}{l}59.2 \\
58.8 \\
59.4 \\
59.7\end{array}$ & $\begin{array}{l}14.4 \\
14.3 \\
15.8 \\
15.1\end{array}$ & $\begin{array}{l}3.6: 1 \\
3.6: 1 \\
3.3: 1 \\
3.5: 1\end{array}$ \\
\hline
\end{tabular}

1) Total Iron as $\mathrm{FeO}$.

the contact of the Red Mountain intrusive mass, at altitudes of 1,200 to 1,900 feet. Only one of these, a low-grade body on the Widow Maker claim of Kearnes and Cooper, appears to be workable. Two lenses of fair concentrating ore, striking $\mathrm{N} .70^{\circ} \mathrm{W}$. and dippling $38^{\circ} \mathrm{SW}$. , crop out at an altitude of 1,700 to 1,800 feet. They are about 200 feet long and 2 to 3.5 feet wide and are separated by 10 feet of nearly barren dunite. Spalling off of the remarkably even-grained ore in the upper band has formed a notch in the cliff.

A little north of the Widow Maker and 300 feet lower a 1foot band of good ore can be traced for about 200 feet. About 600 feet north of the Widow Maker along the contour there is a 1-foot band of ore estimated to contain 40 percent of $\mathrm{Cr}_{2} \mathrm{O}_{3}$. It can be traced 100 feet, and may connect with 2 feet of 20 percent ore westward along the strike. Many smaller stringers are associated with the larger bodies, and independent thin lenses are scattered over the slope. These lenses all strike about $N$. $70^{\circ} \mathrm{W}$. and dip about $45^{\circ} \mathrm{SW}$, although the steep slope swings the trend of their outcrops much nearer to north.

No. 10.--No. 10 is a fairly large ore body exposed fust 200 feet south of the igneous contact on the west slope of the valley. Its outcrop extends intermittently for 450 feet up the slope, and ranges in altitude from 1,560 to 1,860 feet. The width of the ore body varies from 2 to 8 feet. The ore can be traced readily by float where it is not exposed in place. The average trend of the outcrop is $\mathrm{N}_{0} 82^{\circ} \mathrm{E}$. , and the dip appears to be steep. A fault offsets the ore 50 feet northward near the west end of the body, and another one limits the ore on the west.

Although the ore appears to be high grade, much of the chromite has an abnormally low $\mathrm{Cr}_{2} \mathrm{O}_{3}$ content, as shown by the analyses of two channel samples taken across the body at widely separated points. (See table on p. 171.)

The analysis of a grab sample of the ore (No. 45, p. 151) gave 48.55 percent $\mathrm{Cr}_{2} \mathrm{O}_{3}$ and a $\mathrm{Cr}: \mathrm{Fe}$ ratio of $1.88: 1$, which indicates that the chromite varies considerably in composition. It may be that some of it is rich enough to work, but further investigation will be necessary to prove this. No estimate was made of the tonnage in the deposit.

An unusual mode of origin is suggested both by the low tenor of the ore and by the fact that the trend of the ore body diverges at a small angle from that of the banding, which is marked by narrow stringers of disseminated chromite grains. This body may have been deposited in the fractured contact zone of the intrusive by late magmatic or hydrothermal action, or it 
may, like deposit No. 1 , be the result of some form of recrystalifation. The exposures are too poor to make a definite decision on this point.

No. 11.--Ore body No. 11 crops out a quarter of a mile south of the contact of the Red Mountain intrusive mass on the high ridge which forms the divide between Windy River and Fish Creek. The ridge has two crests here, about 150 feet apart, with a shallow talus-filled basin between them. Chromite is exposed on both the east and the west slopes of the ridge.

Analyses of channel samples from deposits 10, 11 , and 12 , Red Mountain

[R. E. Stevens, analyst]

\begin{tabular}{|c|c|c|c|c|c|c|c|}
\hline \multirow{2}{*}{$\begin{array}{l}\text { Ore } \\
\text { body } \\
\text { No. }\end{array}$} & \multirow{2}{*}{$\begin{array}{l}\text { Sam- } \\
\text { ple } \\
\text { No. }\end{array}$} & \multirow[b]{2}{*}{$\begin{array}{l}\text { Length } \\
\text { (feet) }\end{array}$} & \multicolumn{2}{|l|}{ Ore } & \multicolumn{3}{|c|}{ Concentrate } \\
\hline & & & $\begin{array}{c}\mathrm{Cr}_{2} \mathrm{O}_{3} \\
\text { (percent) }\end{array}$ & $\begin{array}{l}\text { Chromite } \\
\text { (percent) }\end{array}$ & $\begin{array}{c}\mathrm{Cr}_{2} \mathrm{O}_{3} \\
\text { (percent) }\end{array}$ & $\begin{array}{c}\text { FeO } \\
\text { (percent) }\end{array}$ & $\mathrm{Cr}: \mathrm{Fe}$ \\
\hline 11 & $\begin{array}{l}\left\{\begin{array}{l}17 \\
18 \\
25 \\
26 \\
27 \\
28 \\
34\end{array}\right\}\end{array}$ & $\begin{array}{l}5.4 \\
3.9 \\
4.0 \\
2.6 \\
4.5 \\
6.8 \\
2.6\end{array}$ & $\begin{array}{l}20.7 \\
13.1 \\
45.0 \\
27.3 \\
24.4 \\
39.7 \\
30.0\end{array}$ & $\begin{array}{l}85 \\
53 \\
77 \\
47 \\
42 \\
68 \\
51\end{array}$ & $\begin{array}{l}24.5 \\
24.8 \\
58.4 \\
58.2 \\
58.4 \\
58.6 \\
58.9\end{array}$ & $\begin{array}{l}22.8 \\
20.5 \\
16.5 \\
18.2 \\
19.7 \\
16.9 \\
16.9\end{array}$ & $\begin{array}{r}0.95: 1 \\
1.05: 1 \\
3.1: 1 \\
2.8: 1 \\
2.6: 1 \\
3.0: 1 \\
3.1: 1\end{array}$ \\
\hline
\end{tabular}

1) Total Iron as geo.

A trench on the eastern crest exposes, from south to north, 4 feet of good ore, 2.6 feet of concentrating ore, 4 feet of dunite, and 4.5 feet of low-grade disseminated ore. The north layer of ore cannot be traced, but the south layer continues eastward down the slope with a strike of $\mathrm{N} .85^{\circ} \mathrm{W}$. and a dip of $65^{\circ} \mathrm{S}$. The width gradually increases to 8 feet 50 feet east, then tapers to 3 feet; it probably pinches out about 100 feet east of the ridge, where, however, it disappears under heavy talus.

On the western crest exposures are poor but there appears to be about 10 feet of very low grade material in several bands. The ore narrows rapidly westward, but a band about 2 feet wide continues for 300 feet down the slope.

It is uncertain whether the ore exposed on the eastern and western crests is part of a single body. The exposures would meet if projected, but no connection could be traced and no float was seen between them. The tonnage estimate is based on the assumption that there are two independent bodies of approximately the size indicated by the outcrops.

No. 12.--The No. 12 ore body is 400 feet west of the $3,000-$ foot knob on the divide south of No. 11. The ore ranges in width from less than 1 foot to $3 \frac{1}{2}$ feet. It has an average width of 2 feet for 300 feet, and narrow extensions at each end. In general it strikes N. $48^{\circ} \mathrm{E}$. and dips $40^{\circ} \mathrm{SE}$., but $1 \mathrm{t}$ has been considerably folded and faulted. A channel sample across the body at the discovery monument gave the results shown in the accompanying table.

A very low grade band crosses the ridge to the east, but $1 t$ has no connection with this deposit. 
No. 13.--Deposit No. 13 consists of a number of narrow bands of disseminated and high-grade chromite in the cliffs north of the south branch of Fish Creek, at an altitude of 2,050 feet. Sharp folding and minor cross faulting have occurred here (pl. 31 , B), but the general strike and dip are N. $30^{\circ}$ E. and $40^{\circ} \mathrm{SE}$. , respectively. The chromite-bearing bands have an aggregate length of 500 feet but are elther so narrow or so low-grade, or both, that probably very little of the material is minable.

About 1,000 feet north there are similar low-grade bands in the cliffs at the same altitude, but they are in a different zone, several hundred feet lower in the section than those at No. is, and have no connection with them.

No. 14.--In approximately the same zone with deposit No. 13, but south of Fish Creek, disseminated chromite crops out along the base of the cliff in a band from 1 to $2 \frac{1}{2}$ feet wide. It is covered in places by talus, but appears to be continuous for at least 900 feet, and probabiy extends for several hundred more. The band occasionally splits into several narrower bands which reunite farther on. The strike is N. $20^{\circ} \mathrm{E}$. and the dip $40^{\circ} \mathrm{SE}$. The ore is for the most part low grade, although some is probably of shipping grade.

No. 15.--Deposit No. 15 is a 1- to 2-foot layer of disseminate chromite at an altitude of approximately 2,400 feet in the cirque east of No. 14. The principal exposure is within a large outcrop of dunite that projects through the talus, but the layer is also exposed in the south wall of the cirque. The strike is $\mathrm{N} .50^{\circ} \mathrm{E}$, and the dip $45^{\circ} \mathrm{SE}$. The layer has a length of about 400 feet, but only the middle hundred feet or so appears rich enough to work.

No. 16.--Deposit No. 16 is a lens of chromite in the steep north wall of the cirque, at an altitude of about 2,800 feet, a quarter of a mile north-northeast of No. 15. It is inaccessible to anyone but an experienced climber. From below the ore appears to be high-grade; a foot or so thick, and about 20 feet long. It is apparently in the same zone as No. 15 and as a narrow band near the top of the next cirque to the north, for all three are about the same distance below a thick layer of pyroxenite. They are not continuous, however.

No. 17.--Deposit No. 17 crops out in the nearly inaccessible cliffs on the northwest face of the pyramidal peak, at an altitude of a little more than 2,400 feet. It consists of interbanded chromite and dunite having a thickness of from 1 to 6 feet. The length is about 350 feet, and the average thickness is 2 feet. Although some of the chromite may be of shipping grade, most of it is only fair concentrating ore. The bands strike $N .50^{\circ} \mathrm{E}$. and dip about $5^{\circ} \mathrm{SE}$. Several small faults have cut the ore, raising the southerly blocks.

No. 18.--No. 18 is a small low-grade body exposed at an altitude of 2,500 feet on the south slope of the ridge running west from Red Mountain. At the northern end 4 feet of disseminated ore is cut off by a fault. About 125 feet south, just above the talus, a l-foot layer and a 2-foot layer of concentrating ore are separated by $2 \frac{1}{2}$ feet of dunite. The ore has been warped; the strike ranges from N. $18^{\circ} \mathrm{W}$. to N. $28^{\circ} \mathrm{W}$, and the dip from $78^{\circ} \mathrm{NE}$. to $35^{\circ} \mathrm{SW}$.

No. 20.--Deposit No. 20 is 3,000 feet northeast of $\operatorname{Red}$ Mountain. It is exposed in a steep cliff, whose talus-covered base is at an altitude of 2,750 feet. Three and a half feet of 
ore at the top of the talus decreases gradually to a thickness of 1 foot 60 feet higher and continues as a narrow band for another 100 feet upward. The layer strikes north and dips about $70^{\circ}$ W., with minor variations due to folding. Four nearly parallel faults, dipping east at low angles, offset the ore from $1 \frac{1}{2}$ to 15 feet. The upper blocks have moved relatively eastward. The fact that the ore is widening downward increases the possibility for a workable ore body. An analysis of a channel sample across the body is shown in the accompanying table (p. 174).

No. 21.--A thousand feet southeast of deposit No. 20, at an altitude of 2,400 feet, there is a very small body of disseminated ore. The main outcrop shows concentrating ore $1 \frac{1}{2}$ feet thick and 10 feet long. The rest of the ore body seems to have been eroded. Smaller lenses are associated with it. The strike is $\mathrm{N} .25^{\circ} \mathrm{W}$. and the dip $80^{\circ} \mathrm{SW}$. A few narrow stringers of ore are exposed 150 feet southeast along the strike.

No. 22.--Three hundred feet northeast of No. 21 a body of chromite is exposed in the creek, only 50 feet from the contact of the Red Mountain intrusive mass. It has a thickness of 3 feet and a length of at least 25 feet. Although it is within the zone of serpentinization and has been partly shattered, remnants of layering, which indicate a strike of $\mathrm{N} .40^{\circ} \mathrm{E}$. and a vertical dip were observed. Considerable high-grade float was seen in the stream bed below the outcrop.

No. 23.--No. 23 is exposed in the bed of a small stream at an altitude of 1,150 feet, 800 feet east of the double bend in Windy River. Three layers of disseminated ore, totaling 2.7 feet, occur in a section of 5.3 feet. They strike N. $33^{\circ} \mathrm{W}$. and dip $55^{\circ}$ SW. A heavy cover of gravel and vegetation conceals the length of the body, but 100 feet south there are large boulders carrying layers of good ore at least 2 feet thick. If these boulders have come from the same ore body, it has increased in thickness and tenor; if not, there is another ore kody near by.

No. 24.--No. 24 crops out at the top of the cliffs at the northwest end of the high bench on which the Star No. 4 is situated. Its altitude is 2,100 to 2,200 feet. The body consists of three. layers of ore separated by $2 \frac{1}{2}$ to 6 feet of barren dun1te. The middle layer is by far the longest and richest. It is 300 feet long and from 1 to 4 feet wide. The upper layer, 130 feet long, is $4 \frac{2}{2}$ feet thick in the center, and tapers toward each end. The lower layer is 70 feet long and a foot or less thick. The layers strike N. $35^{\circ} \mathrm{W}$. and dip $30^{\circ} \mathrm{SW}$. At the eastern end of the ore body a fault, associated with a prominent fold, pl. 3l, A), offsets the ore about 10 feet, the eastern block being raîsed.

Two channel samples, taken at different points across the middle band, gave the percentages shown in the accompanying tab.le (p. 174$)$.

No. 25.--A band of low-grade ore striking $\mathrm{N} .15^{\circ} \mathrm{W}$. and dipping $70^{\circ} \mathrm{SW}$. Is to be seen 500 feet north of the north center end of the Star No. 4. A length of 200 feet is exposed, over which the band averages 2 -feet in width. The ore is estimated to contain 15 or 20 percent of $\mathrm{Cr}_{2} \mathrm{O}_{3}$. The body. is covered by talus to the south, and pinches out at the north end.

No. 26.--No. 26 is a small body of good concentrating ore, with a little high-grade ore, just above the talus in the rocky spur 1,500 feet north-northwest of Red Mountain. Its altitude is 2,350 feet. The ore has a width of about 2 feet, and an 
exposed length of 100 feet. The average strike and dip are N. $10^{\circ} \mathrm{W}$. and $25^{\circ} \mathrm{W}$., but the ore has been severely folded and faulted.

Analyses of channel samples from deposits $20,24,27$, and 28 , Red Mountain

[R. E. Stevens, analyst]

\begin{tabular}{|c|c|c|c|c|c|c|c|}
\hline \multirow{2}{*}{$\begin{array}{l}\text { Ore } \\
\text { body } \\
\text { No. }\end{array}$} & \multirow{2}{*}{$\begin{array}{l}\text { Sam- } \\
\text { ple } \\
\text { No. }\end{array}$} & \multirow[b]{2}{*}{$\begin{array}{l}\text { Length } \\
\text { (feet) }\end{array}$} & \multicolumn{2}{|c|}{ Ore } & \multicolumn{3}{|c|}{ Concentrate } \\
\hline & & & $\begin{array}{c}\mathrm{Cr}_{2} \mathrm{O}_{3} \\
\text { (percent) }\end{array}$ & $\begin{array}{l}\text { Chromite } \\
\text { (percent) }\end{array}$ & $\begin{array}{c}\mathrm{Cr}_{2} \mathrm{O}_{3} \\
\text { (percent) }\end{array}$ & $\begin{array}{c}\text { Feol } \\
(\text { percent })\end{array}$ & Cr:Fe \\
\hline $\begin{array}{l}\overline{20} \\
24 \\
27 \\
28\end{array}$ & 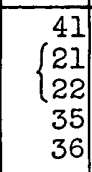 & \begin{tabular}{l|}
2.1 \\
1.5 \\
3.8 \\
5.0 \\
4.0
\end{tabular} & $\begin{array}{l}35.8 \\
45.7 \\
33.5 \\
27.5 \\
19.2\end{array}$ & $\begin{array}{l}61 \\
78 \\
59 \\
50 \\
33\end{array}$ & $\begin{array}{l}58.5 \\
58.4 \\
57.0 \\
55.0 \\
57.6\end{array}$ & $\begin{array}{l}16.4 \\
15.6 \\
17.5 \\
18.1 \\
17.2\end{array}$ & $\begin{array}{l}3.1: 1 \\
3.3: 1 \\
2.9: 1 \\
2.7: 1 \\
2.9: 1\end{array}$ \\
\hline
\end{tabular}

1) Total Iron as FeO.

No. 27.--No. 27 is 500 feet east of No. 18 and at the same altitude, on the south slope of the ridge running west from Red Mountain. A lens of high-grade ore 3.9 feet thick in the middle averages 2.5 feet for a length of 40 feet, and then grades into a poorer ore and continues up the hill for 50 feet. To the south it tapers and pinches out. The strike is $N .20^{\circ} \mathrm{W}$. and the dip $35^{\circ}$ SW.

Seventy-five feet northeast of the high-grade lens a much lower-grade, banded, disseminated ore body is exposed for 50 feet. It is 3 feet thick at the north end, where it is cut off by a fault, and 5 feet thick at the south end, where it passes under talus. Analysis of a channel sample across the lower end of this band gave results as shown in the table above.

No. 28.--A quarter of a mile south of No. 27 , in the cliff at the lip of the large cirque southwest of Red Mountain, an ore body crops out at an altitude of 2,050 feet. It consists of banded disseminated ore 3 to 4 feet thick and 235 feet long. The layer in general strikes $\mathrm{N} .50^{\circ} \mathrm{W}$. and dips $10^{\circ} \mathrm{NE}$., but small folds and faults are numerous. The ore pinches out at each end. Analysis shows the ore to be of low grade. (See table this page.)

No. 29.--A thousand feet west-northwest of No. 28 along the contour there is a small body of good concentrating ore, made up of five lenses from 1 to 10 inches thick in a section of 4 feet. About half the material is ore. The lenses strike $\mathrm{N}$. $45^{\circ} \mathrm{W}$. and dip $22^{\circ} \mathrm{NE}$. They are exposed for 35 feet and covered by talus at each end. The ore may continue for some distance southeast, but exposures to the northwest show only narrow stringers of chromite.

No. 30.--Another small ore body is exposed in cross-section in the cliffs south of Red Mountain at an altitude of 2,350 feet. Two layers, one high-grade and 12 inches thick and the other lower-grade and 19 inches thick, strike north and dip $30^{\circ} \mathrm{W}$. Several strike faults have raised the western blocks.

No. 31.--No. 31 is in the serpentine zone on the divide between the two heads of Fish Creek, 1,500 feet from the contact of the Red Mountain intrusive mass. Its presence was revealed by heavy chromite float, and a little digging uncovered ore in 
place. Neither the extent nor the attitude of the ore could be determined. Although on weathered, slickensided surfaces the ore appears brown and porous, it is actually black and heavy when fresh. An analysis of this ore made for Gill 17/ showed 48.89 percent of $\mathrm{Cr}_{2} \mathrm{O}_{3}$.

\section{Placer deposits}

- Some interest has been displayed in the possibility of recovering chromite from the stream gravels in Windy River, and several placer claims have been staked by G. P. Kearnes and others. To date no attempt has been made to work them, nor have any test pits been sunk. It is impossible to say at present whether these gravels will afford a commercial source of chromite, but the outlook is not good. Glacial action has played a prominent role in the erosion and deposition of this material, and as a consequence 1t appears to be poorly sorted. Moreover, as was pointed out earlier, the specific gravity of chromite is not much greater than that of olivine, and we should not expect a sharply defined pay streak as in the case of gold. Still another unfavorable factor is the tendency of the dunite to break along joints into blocks which do not decompose readily to release the chromite. Thus, although unquestionably a large amount of chromite has been eroded from Red Mountain, and much of it may yet be in the valley of Windy River, it is doubtful whether it can be recovered commercially. The gravels have been tested for platinum by prospectors, but, so far as is known, none was ever found.

1] G111, A. C., op. c1t. (Boll. 742), pp. $40,42$. 
The use of the subjoined mailing label to return this report will be official business, and no postage stamps will be required

\author{
UNITED STATES \\ DEPARTMENT OF THE INTERIOR \\ GEOLOGICAL SURVEY \\ OFFICIAL BUSINESS \\ This label can be used only for returning \\ official publications. The address must not
} be changed.

\section{PENALTY FOR PRIVATE USE TO AVOID PAYMENT OF POSTAGE, $\mathbf{8 3 0 0}$}

\title{
GEOLOGICAL SURVEY,
}

